\title{
Calcium silicate and calcium hydroxide materials for pulp capping: biointeractivity, porosity, solubility and bioactivity of current formulations
}

\author{
Maria Giovanna Gandolfi' ${ }^{1}$ Francesco Siboni ${ }^{1}$, Tatiana Botero ${ }^{2}$, Maurizio Bossù ${ }^{3}$, Francesco Riccitiello ${ }^{4}$ \\ Carlo Prati ${ }^{1,5}$
}

${ }^{1}$ Unit of Odontostomatological Sciences, Laboratory of Biomaterials and Oral Pathology, Department of Biomedical and NeuroMotor Sciences, University of Bologna, Bologna - Italy

${ }^{2}$ Department of Cariology, Restorative Science and Endodontics, University of Michigan, Ann Arbor, Michigan - USA

${ }^{3}$ Unit of Paediatric Dentistry, Department of Odontostomatological and Maxillo-Facial Sciences, University of Rome Sapienza, Rome - Italy

${ }^{4}$ Department of Odontostomatological and Maxillofacial Sciences, University of Naples Federico II, Naples - Italy

${ }^{5}$ Unit of Odontostomatological Sciences, Endodontic Clinical Section, Department of Biomedical and NeuroMotor Sciences, University of Bologna, Bologna - Italy

\begin{abstract}
Aim: The chemical-physical properties of novel and long-standing calcium silicate cements versus conventional pulp capping calcium hydroxide biomaterials were compared.

Methods: Calcium hydroxide-based (Calxyl, Dycal, Life, Lime-Lite) and calcium silicate-based (ProRoot MTA, MTA Angelus, MTA Plus, Biodentine, Tech Biosealer capping, TheraCal) biomaterials were examined. Calcium and hydroxyl ion release, water sorption, interconnected open pores, apparent porosity, solubility and apatite-forming ability in simulated body fluid were evaluated.

Results: All calcium silicate materials released more calcium. Tech Biosealer capping, MTA Plus gel and Biodentine showed the highest values of calcium release, while Lime-Lite the lowest. All the materials showed alkalizing activity except for Life and Lime-Lite. Calcium silicate materials showed high porosity values: Tech Biosealer capping, MTA Plus gel and MTA Angelus showed the highest values of porosity, water sorption and solubility, while TheraCal the lowest. The solubility of watercontaining materials was higher and correlated with the liquid-to-powder ratio. Calcium phosphate (CaP) deposits were noted on materials surfaces after short aging times. Scant deposits were detected on Lime-Lite. A CaP coating composed of spherulites was detected on all calcium silicate materials and Dycal after 28 days. The thickness, continuity and $\mathrm{Ca} / \mathrm{P}$ ratio differed markedly among the materials. MTA Plus showed the thickest coating, ProRoot MTA showed large spherulitic deposits, while TheraCal presented very small dense spherulites.

Conclusions: Calcium silicate-based cements are biointeractive (ion-releasing) bioactive (apatite-forming) functional biomaterials. The high rate of calcium release and the fast formation of apatite may well explain the role of calcium silicate biomaterials as scaffold to induce new dentin bridge formation and clinical healing.
\end{abstract}

Key words: Bioactivity, Calcium hydroxide cements, Calcium silicate cements, MTA cements, Porosity, Pulp capping materials

Accepted: January 10, 2014

\section{INTRODUCTION}

Pulp capping biomaterials are placed as a protective layer on the exposed vital pulp on the floor of deep cavities after removal of deep carious lesions or after traumatic exposure. These protective biomaterials should possess specific bioproperties like biocompatibility, biointeractivity (ion-releasing - i.e., release of biologically relevant ions) and bioactivity (apatite-forming ability) to promote pulp cell activity and the formation of new reparative dentin.

Calcium hydroxide, initially proposed in 1930 as a "remineralizing agent" in direct pulp capping (1), plays a key role in the biological events of reparative dentinogenesis when in close proximity to pulp tissues, due to the release of calcium $(\mathrm{Ca})$ and hydroxyl $(\mathrm{OH})$ ions. An influx of 
these ions from the material toward the pulp even occurs through remaining dentine $(2,3)$. This Ca gradient triggers the recruitment and proliferation of undifferentiated cells from the pulp (4) and activates stem cells (5). The alkaline $\mathrm{pH}$ creates unfavorable conditions for any remaining organisms and exerts an antibacterial/bacteriostatic action $(6,7)$, increasing the expression of alkaline phosphatase and bone morphogenetic protein-2 (BMP-2) and promoting the formation of calcified nodules (8).

For many years, conventional or resin-modified calcium hydroxide/oxide-based materials like Dycal ${ }^{\circledR}$ (since 1962), Life ${ }^{\circledR}$ (since 1979) and Calxy ${ }^{\circledR}$ (since 1988) have been used in clinical practice. Other biomaterials such as Lime-Lite have been proposed as pulp capping agents due to their ability to release $\mathrm{Ca}$ and $\mathrm{OH}$ ions.

Calcium silicate-based materials, now commonly known as mineral trioxide aggregate (MTA) cements, belong to a category of hydraulic self-setting materials, mainly composed of dicalcium and tricalcium silicates. They are hydrophilic radiopaque materials which form a sticky self-setting calcium-silicate-hydrate (CSH) gel (9-12).

The father of the family of calcium silicate cements was a gray Portland cement innovatively introduced as tooth-filling material by Dr. Torabinejad in 1995 as gray ProRoot MTA (13). This cement was initially proposed for root therapies (retrograde surgical filling/root-end sealing and root perforation repair/root and furcation perforations, internal/external resorptions) and revolutionized operative dentistry. White ProRoot MTA was subsequently introduced in 2004 as an iron-free white Portland cement containing bismuth oxide as a radiopacifier (14). ProRoot MTA has recently been considered for pulp therapy (in pulp capping, in deep cervical or radicular lesions and for apexification and apexogenesis) in view of its special chemical-physical and biological properties (15-17), as shown by its ability to release $\mathrm{Ca}^{+2}$ and $\mathrm{OH}^{-}$ions in the surrounding environment $(18,19)$ and to form apatite (bioactivity) (10) when in contact with (body) fluids. MTA Angelus (Angelus Dental Solutions, Londrina, PR, Brazil) formulations were introduced in the following years as a cheaper imitation of both gray and white ProRoot MTA cements.

Calcium silicate-based cements seem to have intrinsic properties tailored for their clinical use (apicoectomy, root perforation and apexification) such as good sealing correlated to expansion, and the ability to set in the presence of fluids $(15,20,21)$, bioactivity $(9,10,22)$, the release of ions acting as epigenetic signals (23) and good biological properties $(15-17,24)$. Therefore, new calcium silicate MTA-like cements such as MTA Plus, Tech Biosealer capping, TheraCal and Biodentine have recently been introduced.

The aim of the present study was to screen the chemical-physical (porosity, water sorption and solubility), biointeractivity and bioactivity properties of current pulp capping materials. Calcium silicate-based materials (Biodentine, MTA Plus, ProRoot MTA, Tech Biosealer capping and TheraCal) were evaluated and compared with conventional long-standing calcium hydroxide/oxidebased materials (Calxyl, Dycal, Life, Lime-Lite).

\section{MATERIALS AND METHODS}

\section{Materials}

Calcium hydroxide-based (Calxyl, Dycal, Life and Lime-Lite) and calcium silicate-based (ProRoot MTA, MTA Angelus, MTA Plus, Biodentine, Tech Biosealer capping and TheraCal) materials were examined. Table I shows the specifications (manufacturer, lot number and composition) of the tested materials.

The materials were prepared according to the manufacturer's instructions. Both Calxyl formulations, TheraCal and Lime-Lite were ready to use without any preparation. Table II reports the calculation of the liquid to powder ratio $(\mathrm{L} / \mathrm{P})$ and the percentage weight of the liquid in the cement paste, and also the results of the trademark registration search.

The fresh materials were placed into PVC molds $(8.0 \pm 0.1 \mathrm{~mm}$ diameter $\times 1.6 \pm 0.1 \mathrm{~mm}$ thickness). Due to recurrent changes in the composition made by the manufacturers, the lot number has been reported to identify an approximate period of production, thereby allowing a comparison of results with studies on materials with the same formulations.

\section{Calcium release and $\mathrm{pH}$}

Material disks ( $\mathrm{n}=13$ for each material) were immediately immersed in $10 \mathrm{~mL}$ of deionized water $(\mathrm{pH}$ 6.8 in polypropylene sealed containers and stored at $37^{\circ} \mathrm{C}$. The soaking water was collected and replaced at 6 endpoints ( 3 and 24 hours and 3, 7, 14 and 28 days). The collected water was analyzed for $\mathrm{pH}$ and $\mathrm{Ca}$ by a potentiometric method under magnetic stirring at room temperature $\left(24^{\circ} \mathrm{C}\right)$. The $\mathrm{pH}$ was measured using a selective temperature-compensated electrode (Sen Tix Sur; WTW, Weilheim, Germany) connected to a multiparameter laboratory meter (inoLab 750; WTW, Weilheim, Germany) previously calibrated with standard solutions. The amount of calcium ions was measured using a calcium probe (Calcium ion electrode; Eutech Instruments Pte Ldt, Singapore) after addition of $0.200 \mathrm{~mL}(2 \%)$ of ionic strength adjuster (ISA; $4 \mathrm{~mol} / \mathrm{L} \mathrm{KCl}$; WTW, Weilheim, Germany). Cumulative calcium release was calculated separately for each of the 13 samples of material by adding up the amounts released at the 6 different endpoints. Then the mean and standard deviation were calculated. 
TABLE I - COMPOSITION OF THE TESTED MATERIALS

\begin{tabular}{|c|c|c|}
\hline Materials (and manufacturers) & Lot number (expiration date: year-month) & Composition \\
\hline \multirow[t]{2}{*}{ Dycal (Dentsply, Milford, DE, USA) } & $81007(2011-09)$ & $\begin{array}{l}\text { Base Paste: 1,3-butylene glycol disalicylate, zinc oxi- } \\
\text { de, calcium phosphate, calcium tungstate, iron oxide } \\
\text { pigments }\end{array}$ \\
\hline & & $\begin{array}{l}\text { Catalyst paste: calcium hydroxide, } \mathrm{N} \text {-ethyl-o/p-toluene } \\
\text { sulphonamide, zinc oxide, titanium oxide, zinc steara- } \\
\text { te, iron oxide pigments }\end{array}$ \\
\hline Life (Kerr, Salerno, Italy) & 3108793 (2012-09) & $\begin{array}{l}\text { Base Paste: butyl benzene sulfonamide, zinc oxide, } \\
\text { calcium hydroxide }\end{array}$ \\
\hline \multirow[t]{2}{*}{ Biodentine (Septodont, France) } & B01767 (2014-02) & Powder: tricalcium silicate \\
\hline & & $\begin{array}{l}\text { Liquid: aqueous calcium chloride solution and } \\
\text { excipients }\end{array}$ \\
\hline \multirow{2}{*}{$\begin{array}{l}\text { MTA Plus (Prevest Detpro Limited, } \\
\text { Jammu, India) }\end{array}$} & $41001(2014-07)$ & Powder: tricalcium and dicalcium silicate \\
\hline & & Liquid 1: water ampules; Liquid 2: gel bottle \\
\hline \multirow[t]{2}{*}{$\begin{array}{l}\text { MTA Angelus (Angelus dental solutions, } \\
\text { Londrina, PR, Brazil) }\end{array}$} & $17939(2016-04)$ & $\begin{array}{l}\text { Powder: } \mathrm{SiO}_{2^{\prime}} \mathrm{K}_{2} \mathrm{O}, \mathrm{Al}_{2} \mathrm{O}_{3^{\prime}} \mathrm{Na}_{2} \mathrm{O}, \mathrm{SO}_{3^{\prime}} \mathrm{CaO}, \mathrm{Bi}_{2} \mathrm{O}_{3^{\prime}} \\
\mathrm{MgO} \text {, insoluble } \mathrm{CaO}, \mathrm{KSO}_{4^{\prime}} \mathrm{NaSO}_{4^{\prime}} \text { crystallized silica }\end{array}$ \\
\hline & & Liquid: $\mathrm{H}_{2} \mathrm{O}$ \\
\hline
\end{tabular}

CEM $=$ Portland cement; DPBS $=$ Dulbecco's Phosphate Buffered Saline.

\section{Porosity, water sorption and solubility}

Material disks ( $\mathrm{n}=13$ for each material group) were prepared as follows. Except for Lime-Lite and TheraCal that were light-cured for 20 seconds, the materials were placed in the molds and allowed to set (at $37^{\circ} \mathrm{C}$ and $99 \%$ relative humidity, following ISO 3107 and 6876) for a period equal to $70 \%$ of the final setting time (i.e., a period $50 \%$ longer than the time stated by the manufacturer, according to ISO 6876) - that is, 2 minutes for Dycal and Life, 9 minutes for Biodentine, 55 minutes for MTA Plus and Tech Biosealer capping, 80 minutes for MTA Angelus and 250 minutes for ProRoot MTA - and then removed from the molds.
Each sample was weighed to determine the initial mass (I) and immediately immersed vertically in $20 \mathrm{~mL}$ of distilled water and placed at $37^{\circ} \mathrm{C}$. After 24 hours of immersion, the specimens were removed from the water, and the mass while suspended in water (S) was determined. The excess water from the surface of each sample was removed using a moistened filter paper $(20 \mathrm{~mL}$ of distilled water dropped on a $9-\mathrm{cm}$ wide $12.5-\mathrm{cm}$ long glass plate covered by a filter paper), and the saturated mass (M) was recorded. Finally, the samples were dried at $37^{\circ} \mathrm{C}$ until the weight was stable, and the final dry mass (D) was recorded. Each weight measurement was repeated 3 times using an analytical balance (Bel Engineering Series 
Calcium silicate and calcium hydroxide materials for pulp capping

TABLE II - LIQUID TO POWDER (L/P) RATIOS AND TRADEMARK REGISTRATION SEARCH

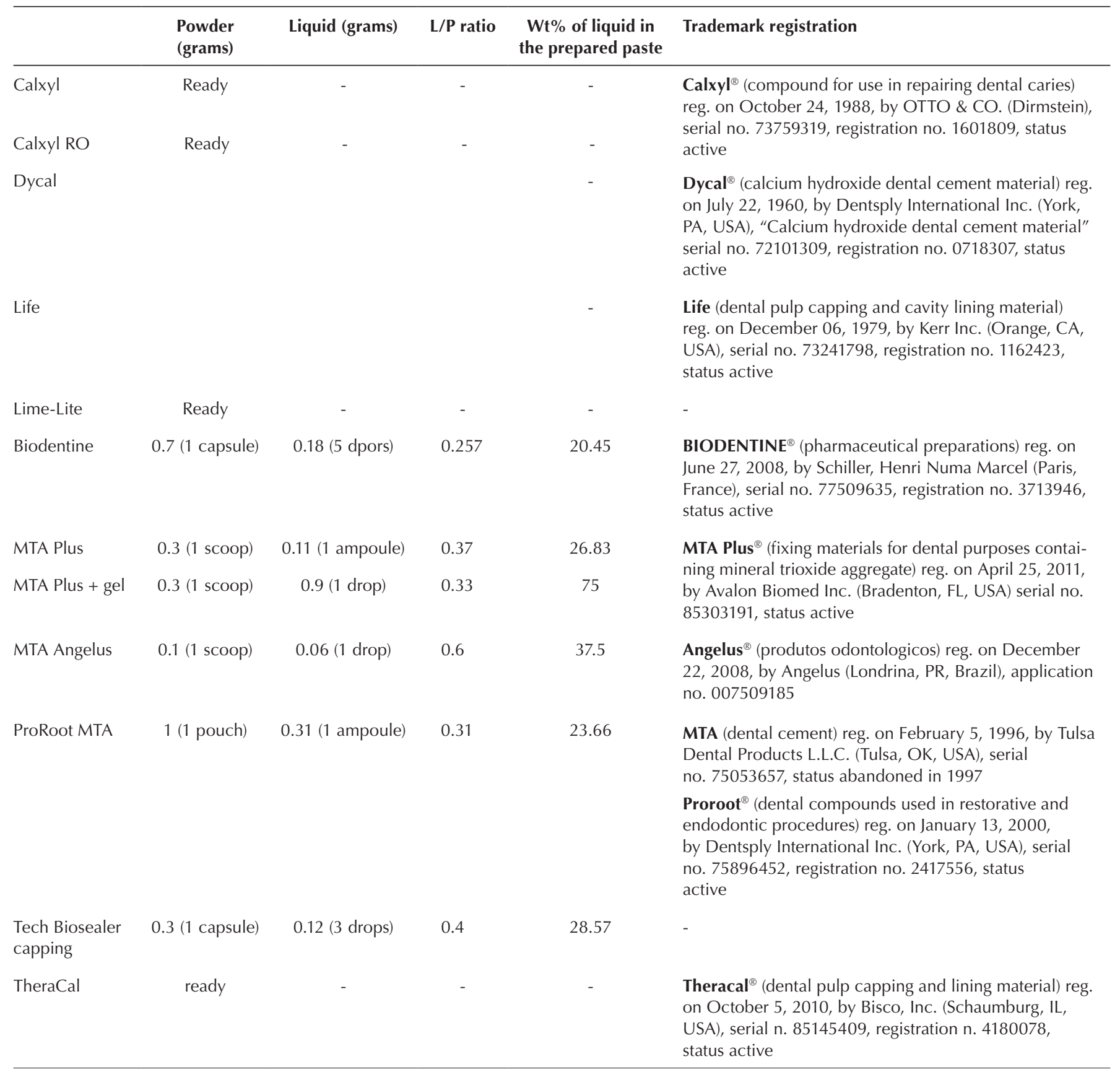

M; Bel Engineering, Monza, MB, Italy) and determined to the nearest $0.001 \mathrm{~g}$.

The exterior volume $\mathrm{V}(\mathrm{V}=\mathrm{M}-\mathrm{S})$, the volume of open pores $\mathrm{V}_{\mathrm{OP}}\left(\mathrm{V}_{\mathrm{OP}}=\mathrm{M}-\mathrm{D}\right)$, the volume of the impervious portion $\mathrm{V}_{\mathbb{I P}}\left(\mathrm{V}_{\mathbb{I P}}=\mathrm{D}-\mathrm{S}\right)$ and the apparent porosity $P(P=[(M-D) / V] \times 100)$ were calculated in cubic centimeters or in percentages, following Archimedes' principle (and according to ASTM C373-88). The water sorption A $(A=[(M-D) / D] \times 100)$ and the solubility $S(S=[(I-D) / D] \times 100)$ were calculated as a percentage of the original weight
(18, 25). ISO 4049 (polymer-based restorative materials), used as both conventional calcium silicate (all MTAs, Biodentine, Tech Biosealer capping) and calcium hydroxide resin-containing (Dycal, Life) cements, are selfcuring materials where the polymerization is chemically activated by mixing, and some resin-containing cements (Lime-Lite, TheraCal) are light-activated materials. Moreover, ISO 4049 guidelines were applied, instead of ISO 9917 (water-based cements) or ADA specification 8 (zinc oxide eugenol cements) recommendations, as some materials 
(Dycal, Life, Lime-Lite, TheraCal) are not water-based and as the residual method is inadequate because it only evaluates the dissolution of water-soluble components and the dispersed/disintegrated portions.

\section{ESEM/EDX surface analysis}

Material disks were immediately immersed vertically in $20 \mathrm{~mL}$ of Hank's Balanced Salt Solution (HBSS; Lonza Walkersville Inc, Walkersville, MD, USA) used as a simulated body fluid and stored at $37^{\circ} \mathrm{C}$ for 1,7 and 28 days $(9,26,27)$. The medium was renewed weekly with fresh HBSS. The surface of each damp sample was examined using an environmental scanning electron microscope (ESEM, Zeiss EVO 50; Carl Zeiss, Oberkochen, Germany) connected to a secondary electron detector for energydispersive X-ray analysis (EDX; EDS Oxford Inca Energy 350; Oxford Instruments, Abingdon, Oxfordshire, UK) using computer-controlled software (Inca Energy Version 18). The discs were placed directly onto the ESEM stub and examined in wet conditions without any previous preparation (the samples were not coated for this analysis) at low vacuum (100 Pa) and an accelerating voltage of $20 \mathrm{kV}$. The resulting electron beam penetration inside the materials depending on density was of a few microns (approx. $2.98 \mu \mathrm{m}$ for calcium silicate cements having approx. $3 \mathrm{~g} / \mathrm{cm}^{3}$ density). The elemental microanalysis of materials (weight \% and atomic \%) was performed with the ZAF correction method, a procedure in which corrections for atomic number effect (Z), absorption (A) and fluorescence (F) are calculated separately. The X-ray microanalysis was performed in full frame and spot mode, to analyze entire areas or specific deposits, respectively. The Ca/P ratio was calculated from the atomic data obtained.

\section{Statistical analysis}

The results were analyzed using 2-way ANOVA followed by RM Student-Newman-Keuls test $(P<0.05)$. In the tables, different letters represent statistically significant differences $(\mathrm{P}<0.05)$ in the same line (capital letters) or in the same column (lowercase letters).

\section{RESULTS}

\section{Calcium release}

All of the materials released $\mathrm{Ca}$ and the release decreased with the soaking time. With the exception of Calxyl formulations that were soluble, all calcium silicate-containing materials released more free calcium ions than $\mathrm{Ca}(\mathrm{OH})_{2}$ resin-containing materials (Tab. III). Calxyl and Calxyl RO showed very high values at 3 hours and 1 day, and then dissolved completely. Tech Biosealer capping, MTA Plus gel and Biodentine showed the highest

TABLE III - CALCIUM RELEASE IN THE SOAKING WATER ( $\mathrm{n}=13$, PER GROUP)

\begin{tabular}{|c|c|c|c|c|c|c|}
\hline & \multicolumn{6}{|c|}{ Calcium released in soaking water (ppm) } \\
\hline Calxyl & $192.6 \pm 23.5^{\mathrm{A}, \mathrm{a}}$ & $323.0 \pm 21.4^{\mathrm{B}, \mathrm{a}}$ & - & - & - & - \\
\hline Calxyl RO & $186.2 \pm 33.0^{\mathrm{A}, \mathrm{a}}$ & $344.0 \pm 23.5^{\mathrm{B}, \mathrm{a}}$ & - & - & - & - \\
\hline Dycal & $26.3 \pm 6.3^{\mathrm{A}, \mathrm{b}}$ & $26.8 \pm 8.7^{\mathrm{A}, \mathrm{b}, \mathrm{c}}$ & $21.7 \pm 11.5^{\mathrm{A}, \mathrm{a}}$ & $16.1 \pm 5.4^{\mathrm{A}, \mathrm{a}}$ & $18.0 \pm 2.4^{\mathrm{A}, \mathrm{a}, \mathrm{b}}$ & $15.2 \pm 5.3^{\mathrm{A}, \mathrm{a}, \mathrm{b}, \mathrm{c}}$ \\
\hline Lime-Lite & $5.2 \pm 2.0^{\mathrm{A}, \mathrm{c}, \mathrm{d}}$ & $6.7 \pm 2.5^{\mathrm{A}, \mathrm{d}, \mathrm{e}}$ & $3.8 \pm 0.9^{\mathrm{A}, \mathrm{b}, \mathrm{c}}$ & $6.8 \pm 1.5^{\mathrm{A}, \mathrm{a}}$ & $5.0 \pm 0.5^{\mathrm{A}, \mathrm{b}, \mathrm{c}}$ & $7.0 \pm 2.2^{\mathrm{A}, \mathrm{b}, \mathrm{c}}$ \\
\hline Biodentine & $95.3 \pm 13.0^{\mathrm{A}, \mathrm{e}}$ & $18.0 \pm 5.6^{\mathrm{B}, \mathrm{c}, \mathrm{d}}$ & $21.7 \pm 9.4^{\mathrm{B}, \mathrm{a}}$ & $43.2 \pm 2.8^{\mathrm{c}, \mathrm{b}}$ & $27.7 \pm 8.5^{\mathrm{B}, \mathrm{a}}$ & $30.3 \pm 5.9^{\mathrm{B}, \mathrm{a}}$ \\
\hline MTA Plus & $46.6 \pm 12.8^{\mathrm{A}, \mathrm{f}}$ & $21.5 \pm 8.0^{\mathrm{B}, \mathrm{c}, \mathrm{d}, \mathrm{f}}$ & $15.8 \pm 4.1^{\mathrm{B}, \mathrm{a}}$ & $12.2 \pm 5.0^{\mathrm{B}, \mathrm{a}}$ & $9.2 \pm 2.2^{\mathrm{B}, \mathrm{b}, \mathrm{c}}$ & $7.2 \pm 3.6^{\mathrm{B}, \mathrm{b}, \mathrm{c}}$ \\
\hline MTA Plus + gel & $97.8 \pm 27.8^{\mathrm{A}, \mathrm{e}}$ & $65.2 \pm 28.0^{\mathrm{B}, \mathrm{g}}$ & $18.9 \pm 6.8^{\mathrm{C}, a}$ & $12.3 \pm 3.8^{\mathrm{C}, \mathrm{a}}$ & $11.5 \pm 2.6^{\mathrm{C}, \mathrm{a}, \mathrm{b}, \mathrm{c}}$ & $23.3 \pm 12.7^{\mathrm{C}, \mathrm{a}}$ \\
\hline Tech Biosealer capping & $162.7 \pm 28.2^{\mathrm{A}, \mathrm{g}}$ & $28.4 \pm 4.1^{\mathrm{B}, \mathrm{b}, \mathrm{c}}$ & $19.7 \pm 6.0^{\mathrm{B}, \mathrm{a}}$ & $110.9 \pm 15.4^{\mathrm{C}, \mathrm{d}}$ & $23.9 \pm 3.2^{\mathrm{B}, \mathrm{a}}$ & $26.1 \pm 3.7^{\mathrm{B}, \mathrm{a}}$ \\
\hline TheraCal & $18.0 \pm 2.3^{\mathrm{A}, \mathrm{b}, \mathrm{c}}$ & $34.2 \pm 2.1^{\mathrm{A}, \mathrm{b}, \mathrm{f}}$ & $27.0 \pm 4.4^{\mathrm{A}, \mathrm{a}}$ & $12.6 \pm 1.7^{\mathrm{A}, \mathrm{a}}$ & $21.9 \pm 5.8^{\mathrm{A}, \mathrm{a}}$ & $23.9 \pm 1.0^{\mathrm{A}, \mathrm{a}}$ \\
\hline Distilled water & $1.0 \pm 0.8^{\mathrm{A}, \mathrm{d}}$ & $0.6 \pm 1.1^{\mathrm{A}, \mathrm{e}}$ & $1.8 \pm 0.7^{\mathrm{A}, \mathrm{C}}$ & $1.6 \pm 0.8^{A, e}$ & $1.2 \pm 0.9^{A, C}$ & $1.1 \pm 0.6^{\mathrm{A}, \mathrm{C}}$ \\
\hline
\end{tabular}

Different letters represent statistically significant differences (2-way RM ANOVA followed by Student-Newman-Keuls test, $\mathrm{P}<0.05$ ) in the same line (capital letters) or in the same column (lowercase letters). ppm = parts per million. 
Ca release at both short (3 hours) and long times (28 days). By contrast, MTA Plus and MTA Angelus showed fairly high values at short endpoints that strongly decreased over time, in particular MTA Plus. The Ca release of ProRoot MTA and TheraCal was not marked but constant (no statistically significant changes over time). Almost constant values were also obtained for the Dycal, Life and LimeLite groups. The amount of calcium released by Lime-Lite was negligible.

Cumulative calcium release (Tab. IV) at all tested endpoints was highest for Tech Biosealer capping and high for Biodentine and MTA Plus gel. Lime-Lite showed the lowest cumulative release. In particular, after 28 days of soaking, the total amount of Ca released was 370 parts per million (ppm) from Tech Biosealer capping, $245 \mathrm{ppm}$ from Biodentine and $230 \mathrm{ppm}$ from MTA Plus, and only 35 ppm from Lime-Lite.

\section{Alkalizing activity ( $\mathrm{pH}$ of soaking water)}

All of the materials induced the alkalization of the soaking water that decreased with time but was still present at 28 days (Tab. V). All calcium silicate-containing materials basified the soaking water more than the other materials, except the 2 Calxyl soluble formulations.

Calxyl and Calxyl RO showed the highest $\mathrm{pH}$ values $(\mathrm{pH}>12)$ until their complete dissolution at 1 day. Dycal showed $\mathrm{pH} \sim 10$ at all endpoints. Life, Lime-Lite and Ther$\mathrm{aCal}$ induced the lowest $\mathrm{pH}$ alkalization, and the water $\mathrm{pH}$ in the presence of Life was near to neutrality at all endpoints. All MTAs, Biodentine, Tech Biosealer capping and TheraCal alkalized the soaking water to $\mathrm{pH} 11-12$ at short times (until 3 days), then decreased and after 14 days the $\mathrm{pH}$ was 7-8. Only Dycal, Biodentine and MTA Angelus were able to keep the $\mathrm{pH}$ higher than 9 after 28 days of soaking. The moderate alkalizing activity of TheraCal was the most constant among all of the materials.

\section{Porosity water sorption and solubility}

The volume of open pores varied widely in the different materials, with statistically significant differences (Tab. VI), and calcium silicate-containing cements showed the highest values. The highest values of open porosity and apparent porosity were measured for MTA Angelus, Tech Biosealer capping and both MTA Plus formulations, followed by ProRoot MTA, Biodentine and TheraCal. The lowest values were detected for Dycal and Life. The open porosity of the 2 Calxyl formulations was not calculated, as the materials did not set.

The solubility values showed a wide range of variation among the different materials (Tab. VI). The resincontaining materials yielded the lowest values, while the water-containing calcium silicate-based materials

TABLE IV - CUMULATIVE CALCIUM RELEASE IN THE SOAKING WATER (ppm, n=13)

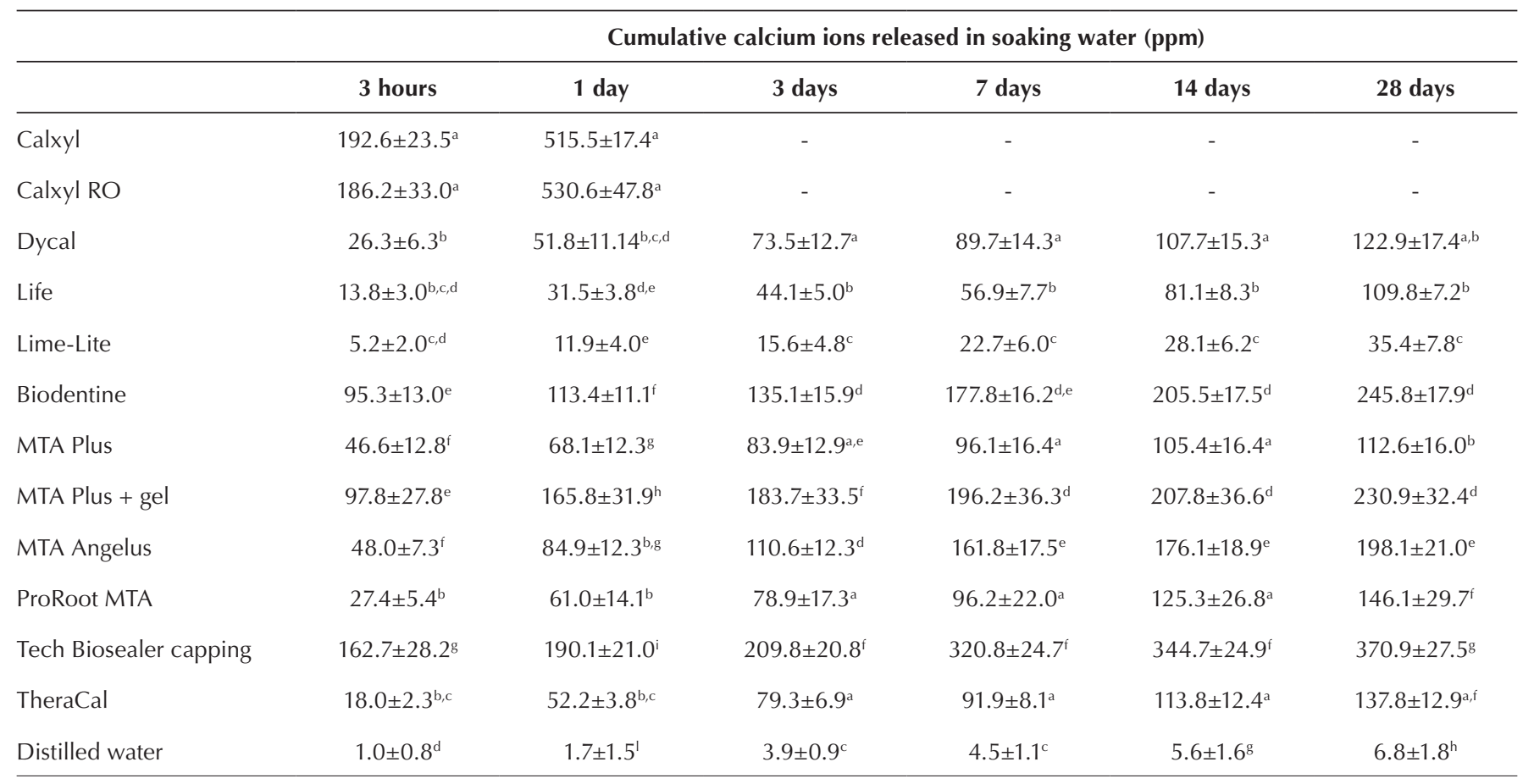

Different letters represent statistically significant differences (2-way RM ANOVA followed by Student-Newman-Keuls test, $\mathrm{P}<0.05$ ) in the same line (capital letters) or in the same column (lowercase letters). ppm = parts per million. 
Gandolfi et al

TABLE V - SOAKING WATER pH IN THE PRESENCE OF THE MATERIALS ( $\mathrm{n}=13$, PER GROUP)

\begin{tabular}{|c|c|c|c|c|c|c|}
\hline & \multicolumn{6}{|c|}{$\mathrm{pH}$ of soaking water } \\
\hline & 3 hours & 1 day & 3 days & 7 days & 14 days & 28 days \\
\hline Calxyl & $12.34 \pm 0.09^{\mathrm{A}, \mathrm{a}}$ & $12.73 \pm 0.17^{\mathrm{A}, \mathrm{a}}$ & - & - & - & - \\
\hline Calxyl RO & $12.40 \pm 0.08^{\mathrm{A}, \mathrm{a}}$ & $12.88 \pm 0.05^{\mathrm{A}, \mathrm{a}}$ & - & - & - & - \\
\hline Dycal & $10.29 \pm 0.48^{\mathrm{A}, \mathrm{b}}$ & $10.49 \pm 0.41^{\mathrm{A}, \mathrm{b}}$ & $10.13 \pm 0.28^{\mathrm{A}, \mathrm{a}, \mathrm{b}}$ & $9.16 \pm 0.60^{\mathrm{B}, \mathrm{a}}$ & $9.62 \pm 0.46^{\mathrm{B}, \mathrm{a}}$ & $9.81 \pm 0.61^{\mathrm{A}, \mathrm{B}, \mathrm{a}}$ \\
\hline Life & $7.33 \pm 0.86^{\mathrm{A}, \mathrm{c}}$ & $7.54 \pm 0.81^{A, c, d}$ & $7.45 \pm 0.53^{\mathrm{A}, \mathrm{C}}$ & $7.48 \pm 0.21^{\mathrm{A}, \mathrm{b}, \mathrm{c}}$ & $7.49 \pm 0.25^{\mathrm{A}, \mathrm{b}}$ & $7.62 \pm 0.11^{\mathrm{A}, \mathrm{b}, \mathrm{c}}$ \\
\hline Biodentine & $11.60 \pm 0.15^{\mathrm{A}, \mathrm{e}, \mathrm{f}}$ & $11.63 \pm 0.51^{\mathrm{A}, \mathrm{f}}$ & $10.96 \pm 0.72^{\mathrm{B}, \mathrm{e}}$ & $9.21 \pm 0.50^{\mathrm{C}, \mathrm{d}}$ & $9.43 \pm 0.28^{\mathrm{C}, \mathrm{a}}$ & $9.26 \pm 0.66^{\mathrm{C}, \mathrm{e}}$ \\
\hline MTA Plus & $11.77 \pm 0.34^{\mathrm{A}, \mathrm{e}, \mathrm{f}}$ & $11.48 \pm 0.59^{\mathrm{A}, \mathrm{f}}$ & $10.10 \pm 1.06^{\mathrm{B}, \mathrm{b}}$ & $8.74 \pm 0.54^{\mathrm{c}, \mathrm{d}}$ & $8.68 \pm 0.29^{\mathrm{c,c}}$ & $8.24 \pm 0.45^{\mathrm{c}, \mathrm{b}}$ \\
\hline MTA Plus + gel & $12.00 \pm 0.23^{\mathrm{A}, \mathrm{a}, \mathrm{e}}$ & $12.52 \pm 0.27^{\mathrm{A}, \mathrm{a}}$ & $10.90 \pm 1.37^{\mathrm{B}, \mathrm{e}}$ & $9.99 \pm 1.18^{\mathrm{C}, \mathrm{e}}$ & $8.60 \pm 0.70^{\mathrm{D}, \mathrm{c}}$ & $7.99 \pm 0.22^{\mathrm{D}, \mathrm{b}}$ \\
\hline MTA Angelus & $11.31 \pm 0.22^{\mathrm{A}, \mathrm{f}, \mathrm{g}}$ & $11.22 \pm 0.11^{\mathrm{A}, \mathrm{f}}$ & $11.15 \pm 0.72^{\mathrm{A}, \mathrm{e}}$ & $11.29 \pm 0.65^{\mathrm{A}, \mathrm{f}}$ & $10.34 \pm 0.59^{\mathrm{B}, \mathrm{d}}$ & $8.94 \pm 0.73^{\mathrm{C}, \mathrm{e}}$ \\
\hline TheraCal & $9.53 \pm 0.15^{\mathrm{A}, \mathrm{h}}$ & $7.89 \pm 0.02^{\mathrm{B}, \mathrm{c}}$ & $8.54 \pm 0.29^{\mathrm{B}, \mathrm{d}}$ & $8.00 \pm 0.26^{\mathrm{B}, \mathrm{b}}$ & $8.43 \pm 0.22^{\mathrm{B}, \mathrm{c}, \mathrm{e}}$ & $8.12 \pm 0.07^{\mathrm{B}, \mathrm{b}}$ \\
\hline Distilled water & $6.82 \pm 0.43^{\mathrm{A}, \mathrm{C}}$ & $7.05 \pm 0.13^{\mathrm{A}, \mathrm{d}}$ & $7.03 \pm 0.44^{\mathrm{A}, \mathrm{c}}$ & $7.12 \pm 0.15^{\mathrm{A}, \mathrm{C}}$ & $6.63 \pm 0.22^{\mathrm{A}, \mathrm{f}}$ & $6.94 \pm 0.21^{\mathrm{A}, \mathrm{d}}$ \\
\hline
\end{tabular}

Different letters represent statistically significant differences (2-way RM ANOVA followed by Student-Newman-Keuls test, $\mathrm{P}<0.05$ ) in the same line (capital letters) or in the same column (lowercase letters).

TABLE VI - POROSITY, WATER SORPTION AND SOLUBILITY OF THE MATERIALS ( $\mathrm{n}=13$, PER GROUP)

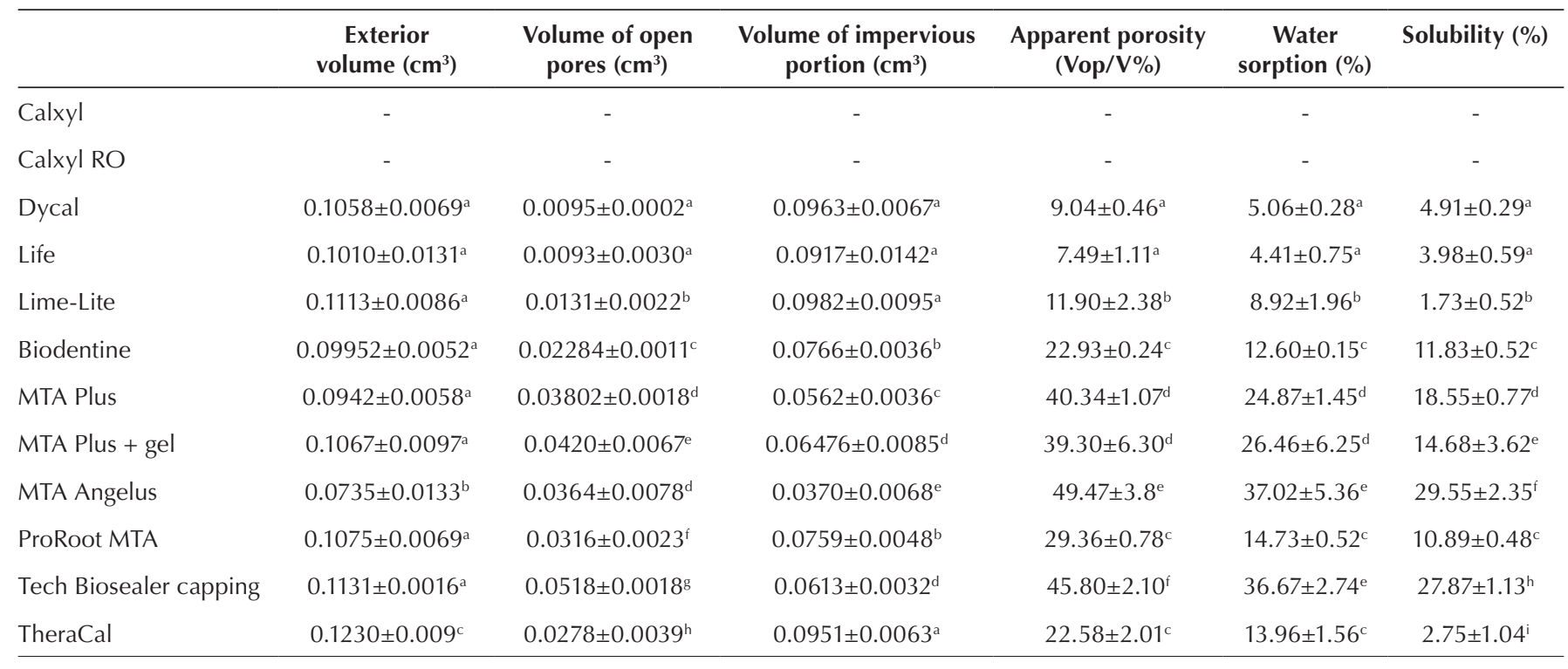

Different letters represent statistically significant differences (2-way RM ANOVA followed by Student-Newman-Keuls test, P $<0.05)$ in the same line (capital letters) or in the same column (lowercase letters).

showed the highest solubility. Biodentine showed the lowest solubility among the calcium silicate materials, but this material contained a very small amount of mixing fluid. MTA Angelus and Tech Biosealer capping showed the highest values of solubility. The least soluble material was Lime-Lite. The solubility of both Calxyl compositions was complete.
The water sorption values showed a similar trend (Tab. VI).

\section{ESEM-EDX morphological and chemical surface analysis}

EDX analysis of the freshly prepared materials yielded the qualitative semiquantitative elemental composition. 
$\mathrm{Ca} / \mathrm{P}$ deposits differing in amount and density were detected by ESEM on the surface of all materials from 7 days of immersion in HBSS.

Dycal

Fresh Dycal (Fig. 1) showed a uniform surface and displayed $\mathrm{Ca}$ and $\mathrm{O}$ elements (from calcium hydroxide) together with $\mathrm{P}(4 \% \mathrm{wt}$, from the calcium phosphate component), W (2.6\% wt, from calcium tungstate), Ti (from titanium oxide), $\mathrm{Zn}$ (from zinc oxide and from zinc stearate) and S (2.88\% wt) and C (25.72\% wt) from toluene sulphonamide and from glycol disalicylate, respectively. The $\mathrm{Ca} / \mathrm{P}$ ratio of 3.75 reflected the contribution of $\mathrm{Ca}$ from calcium hydroxide, calcium phosphate and calcium tungstate. $\mathrm{N}$ from sulphonamide was not detected at any time. At 7 days, the reflexes of $C$ (from the organic components) and $\mathrm{S}$ decreased in intensity while $\mathrm{Ca}$ and $\mathrm{P}$ reflexes increased; $\mathrm{W}$ peaks disappeared and $\mathrm{Na}, \mathrm{Mg}$ and $\mathrm{Cl}$ elements (from HBSS) were detected. Overall the reflexes of the ingredients decreased in intensity with the soaking time for the formation of a cover of calcium phosphate deposits. At 28 days, a CaP coating layer was present on the surface, although its thickness was insufficient to impair the detection of $\mathrm{Ti}$ and $\mathrm{Zn}$ elements; the $\mathrm{Ca} / \mathrm{P}$ ratio was 1.64. The material showed a fair bioactivity.

Life

Freshly mixed Life (Fig. 1) showed a finely granular uniform surface displaying Ca together Ti $(2.3 \% \mathrm{wt}$, from titanium oxide), Zn (5.3\% wt, from zinc oxide), Ba (11\% wt, from barium sulphate), S (5.4\% wt) and C (33\% wt) (from benzene sulphonamide and from methyl salicylate phases) and traces of $\mathrm{Si}(0.63 \% \mathrm{wt}$, from a nondisclosed ingredient). $\mathrm{N}$ from sulphonamide was not detected. The reflex intensity of the components diminished with time, while the $\mathrm{P}$ reflex appeared and $\mathrm{Na}, \mathrm{Mg}$ and $\mathrm{Cl}$ (from the HBSS) were detected. However weakened $\mathrm{C}$ and $\mathrm{Ti}$ reflexes were still present at 28 days due to a nonuniform and/or thin layer of $\mathrm{CaP}$ deposits covering the surface. The $\mathrm{Ca} / \mathrm{P}$ atomic ratio was 1.42 and reflected the contribution of calcium hydroxide. Life showed little bioactivity.

\section{Lime-Lite}

Fresh Lime-Lite (Fig. 1) showed a smooth matrix surface filled with nanoparticles, likely hydroxyapatite. EDX revealed C (57\% wt, from methacrylate resin), Ca (1.84\% wt) and $\mathrm{P}(0.78 \% \mathrm{wt})$ (from hydroxyapatite). Ba (7\% wt), $\mathrm{S}(1.77 \% \mathrm{wt})$ and Si $(1.34 \% \mathrm{wt})$ from nondisclosed ingredients (possibly $\mathrm{Ba}$ and $\mathrm{S}$ from barium sulphate and Si from silicon-containing urethane) were also noted. Si reflexes decreased in intensity with the soaking time, while $\mathrm{Na}, \mathrm{Mg}$ and $\mathrm{Cl}$ (from the HBSS) appeared together with P. Traces of $F$ were detected at 7 days. Scant CaP deposits were noted from 7 days, and at 28 days, the $\mathrm{Ca} / \mathrm{P}$ atomic ratio was 1.25 .

\section{Biodentine}

Freshly mixed Biodentine (Fig. 1) showed a uniform surface containing interspersed granules approx. $5 \mu \mathrm{m}$ wide, and displayed $\mathrm{Ca}$ and Si from tricalcium silicate and $\mathrm{Cl}$ (from the aqueous calcium chloride). $\mathrm{Zr}(1.82 \% \mathrm{wt}$ ), $\mathrm{C}(6.57 \% \mathrm{wt})$ and $\mathrm{N}(3.95 \% \mathrm{wt})$ reflexes (from components not indicated by the manufacturer, likely zirconium oxide, carbonates and organic components) were also detected. No Al was present at any time. With soaking time in HBSS, the reflexes of $\mathrm{N}$ and $\mathrm{Zr}$ disappeared, the Si component decreased in intensity and $\mathrm{Na}, \mathrm{Mg}$ and $P$ elements from HBSS became detectable. The surface was covered by globular precipitates, and $P$ reflexes increased in intensity with time. At 28 days the $\mathrm{Ca} / \mathrm{P}$ ratio was 2.74.

Additional ESEM-EDX analyses on unhydrated powder (Fig. 2) revealed the following elements in weight percentage (\% wt): C (4.34\%), N (5.29\%), O (42\%), F (0.1\%), Si (7.3\%), Ca (39\%) and $\operatorname{Zr}(2.2 \%)$, demonstrating the presence of undisclosed organic additives and a radiopacifier in the anhydrous powder.

\section{MTA Angelus}

Freshly mixed MTA Angelus (Fig. 3) showed an irregular surface with evident granules of different sizes $(2-10 \mu \mathrm{m})$ and elongated particles (approx. 30- $\mu \mathrm{m}$ long), and displayed EDX reflexes of $\mathrm{Ca}, \mathrm{Si}, \mathrm{C}(5.12 \% \mathrm{wt}$, from carbonates), $\mathrm{Bi}(8.48 \% \mathrm{wt}$, from bismuth oxide) and $\mathrm{Al}$ (1.97\% wt) and $\mathrm{S}(1.10 \% \mathrm{wt}$, likely from calcium sulphate). After 7 days in HBSS, the surface was covered by aggregated spherulites forming CaP deposits. EDX showed Ca, Si, P, $\mathrm{C}, \mathrm{Mg}, \mathrm{Na}$ and $\mathrm{Cl}$ reflexes. $\mathrm{Al}$ and $\mathrm{S}$ were still detectable with decreased intensity, whereas $\mathrm{Bi}$ was not detected. At 28 days of immersion, the increase in $\mathrm{P}$ was clearly evident. $\mathrm{Si}, \mathrm{Al}, \mathrm{Bi}$ and $\mathrm{C}$ elements were undetectable. An irregular $\mathrm{CaP}$ coating was present on the surface, and the $\mathrm{Ca} / \mathrm{P}$ atomic ratio was approx. 2.2.

\section{MTA Plus}

Freshly mixed MTA Plus (Fig. 3) showed a granular surface with uniform particle size. EDX displayed $\mathrm{Ca}$ and $\mathrm{Si}$ from dicalcium and tricalcium silicate, $\mathrm{S}(2.56 \%$ wt), $\mathrm{Al}(0.59 \% \mathrm{wt})$ and $\mathrm{Bi}(6.11 \% \mathrm{wt}) . \mathrm{C}(3.67 \% \mathrm{wt}), \mathrm{Na}$, $\mathrm{Mg}$ and $\mathrm{K}$ were also detected. At 7 days, $\mathrm{Si}$ and $\mathrm{Bi}$ reflexes decreased in intensity, $\mathrm{S}$ became undetectable and $\mathrm{C}$ increased in intensity. Al was detectable at all times. 

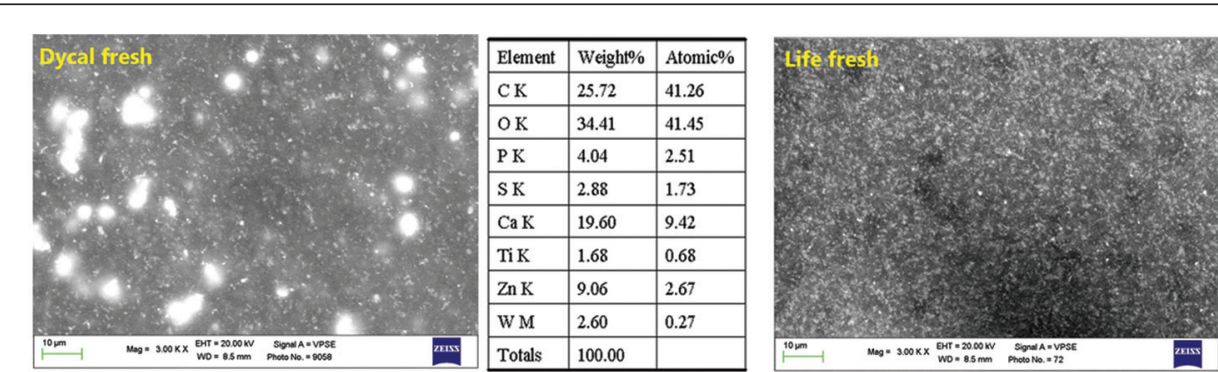

\begin{tabular}{|l|c|c|}
\hline Element & Weight\% & Atomic\% \\
\hline $\mathrm{C} \mathrm{K}$ & 33.72 & 52.14 \\
\hline $\mathrm{O} \mathrm{K}$ & $\mathbf{3 0 . 3 4}$ & 35.22 \\
\hline $\mathrm{Si} \mathrm{K}$ & $\mathbf{0 . 6 3}$ & 0.42 \\
\hline $\mathrm{S} \mathrm{K}$ & 5.42 & $\mathbf{3 . 1 4}$ \\
\hline $\mathrm{Ca} \mathrm{K}$ & $\mathbf{1 0 . 6 8}$ & 4.95 \\
\hline $\mathrm{T} \mathrm{K}$ & $\mathbf{3 . 0 5}$ & 1.18 \\
\hline $\mathrm{Zn} \mathrm{K}$ & 5.16 & 1.47 \\
\hline $\mathrm{Ba} \mathrm{L}$ & 11.00 & 1.49 \\
\hline Totals & $\mathbf{1 0 0 . 0 0}$ & \multicolumn{1}{|c|}{} \\
\hline
\end{tabular}

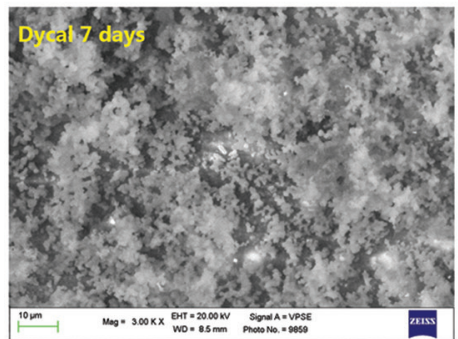

\begin{tabular}{|l|l|l|}
\hline Element & Weight\% & Atomic\% \\
\hline $\mathrm{C} \mathrm{K}$ & 5.98 & 10.62 \\
\hline $\mathrm{O} \mathrm{K}$ & 45.49 & 60.69 \\
\hline $\mathrm{Na} \mathrm{K}$ & 3.02 & 2.81 \\
\hline $\mathrm{Mg} \mathrm{K}$ & 1.20 & 1.05 \\
\hline $\mathrm{P} \mathrm{K}$ & 11.75 & 8.10 \\
\hline $\mathrm{S} \mathrm{K}$ & 0.49 & 0.33 \\
\hline $\mathrm{Cl} \mathrm{K}$ & 3.90 & 2.35 \\
\hline $\mathrm{Ca} \mathrm{K}$ & 23.26 & 12.39 \\
\hline $\mathrm{Ti} \mathrm{K}$ & 0.60 & 0.27 \\
\hline $\mathrm{Zn} \mathrm{K}$ & 4.30 & 1.40 \\
\hline Totals & 100.00 & \\
\hline $\mathrm{Ca} / \mathrm{P}$ & & 1.53 \\
\hline
\end{tabular}
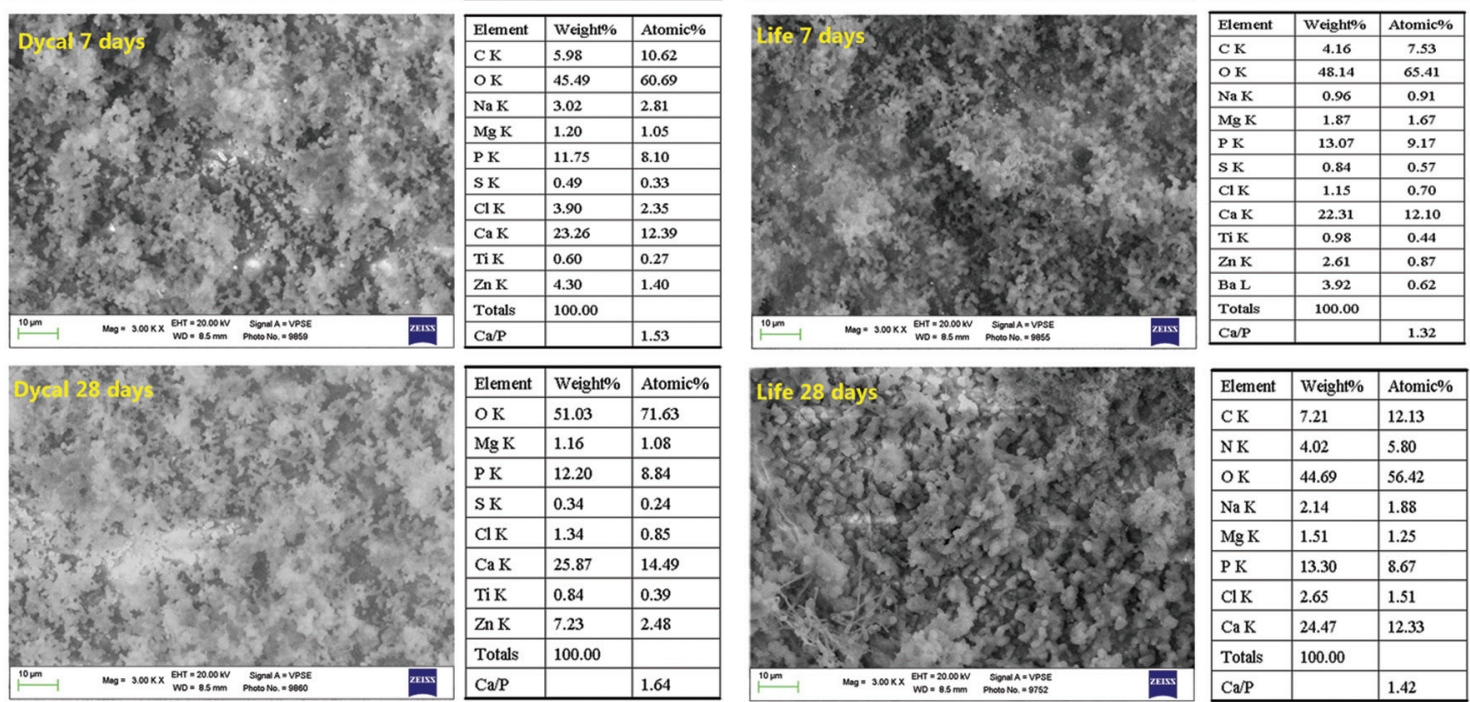

\begin{tabular}{|l|l|l|}
\hline Element & Weight\% & Atomic\% \\
\hline $\mathrm{O} \mathrm{K}$ & 51.03 & 71.63 \\
\hline $\mathrm{Mg} \mathrm{K}$ & 1.16 & 1.08 \\
\hline $\mathrm{P} \mathrm{K}$ & 12.20 & 8.84 \\
\hline $\mathrm{S} \mathrm{K}$ & 0.34 & 0.24 \\
\hline $\mathrm{Cl} \mathrm{K}$ & 1.34 & 0.85 \\
\hline $\mathrm{Ca} \mathrm{K}$ & 25.87 & 14.49 \\
\hline $\mathrm{Ti} \mathrm{K}$ & 0.84 & 0.39 \\
\hline $\mathrm{Zn} \mathrm{K}$ & 7.23 & 2.48 \\
\hline Totals & 100.00 & \\
\hline $\mathrm{C}$ CaP & & 1.64 \\
\hline
\end{tabular}

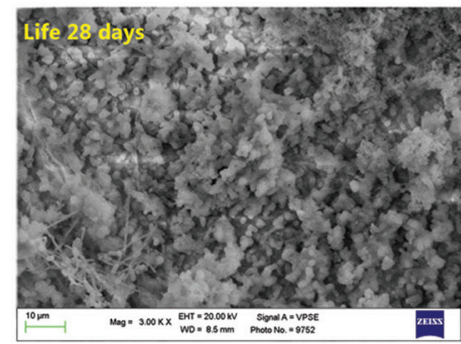

\begin{tabular}{|l|l|l|}
\hline Element & Weight\% & Atomic\% \\
\hline $\mathrm{C} \mathrm{K}$ & 7.21 & 12.13 \\
\hline $\mathrm{N} \mathrm{K}$ & 4.02 & 5.80 \\
\hline $\mathrm{O} \mathrm{K}$ & 44.69 & 56.42 \\
\hline $\mathrm{Na} \mathrm{K}$ & 2.14 & 1.88 \\
\hline $\mathrm{Mg} \mathrm{K}$ & 1.51 & 1.25 \\
\hline $\mathrm{P} \mathrm{K}$ & 13.30 & 8.67 \\
\hline $\mathrm{Cl} \mathrm{K}$ & 2.65 & 1.51 \\
\hline $\mathrm{Ca} \mathrm{K}$ & 24.47 & 12.33 \\
\hline Totals & 100.00 & \\
\hline $\mathrm{C}$ Ca/P & & 1.42 \\
\hline
\end{tabular}

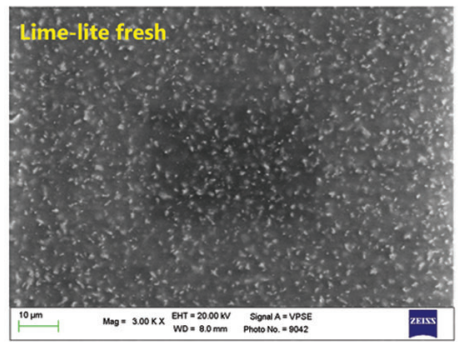

\begin{tabular}{|l|c|c|}
\hline Element & Weight\% & Atomic\% \\
\hline $\mathrm{C} \mathrm{K}$ & 57.00 & 69.16 \\
\hline $\mathrm{O} \mathrm{K}$ & 30.26 & 27.56 \\
\hline $\mathrm{Si} \mathrm{K}$ & 1.34 & 0.69 \\
\hline $\mathrm{P} \mathrm{K}$ & 0.78 & 0.37 \\
\hline $\mathrm{S} \mathrm{K}$ & 1.77 & 0.80 \\
\hline $\mathrm{Ca} \mathrm{K}$ & 1.84 & 0.67 \\
\hline Ba L & 7.01 & 0.74 \\
\hline Totals & 100.00 & \\
\hline
\end{tabular}

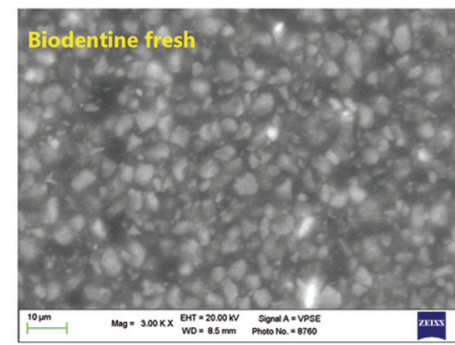

\begin{tabular}{|l|l|l|}
\hline Element & Weight\% & Atomic\% \\
\hline $\mathrm{C} \mathrm{K}$ & 6.57 & 12.30 \\
\hline $\mathrm{N} \mathrm{K}$ & 3.95 & 6.34 \\
\hline $\mathrm{O} \mathrm{K}$ & 35.29 & 49.58 \\
\hline $\mathrm{Al} \mathrm{K}$ & 0.05 & 0.04 \\
\hline $\mathrm{Si} \mathrm{K}$ & 5.91 & 4.73 \\
\hline $\mathrm{Cl} \mathrm{K}$ & 7.47 & 4.73 \\
\hline $\mathrm{Ca} \mathrm{K}$ & 38.92 & 21.83 \\
\hline $\mathrm{Zr} \mathrm{L}$ & 1.82 & 0.45 \\
\hline Totals & 100.00 & \multicolumn{1}{|l}{} \\
\hline
\end{tabular}
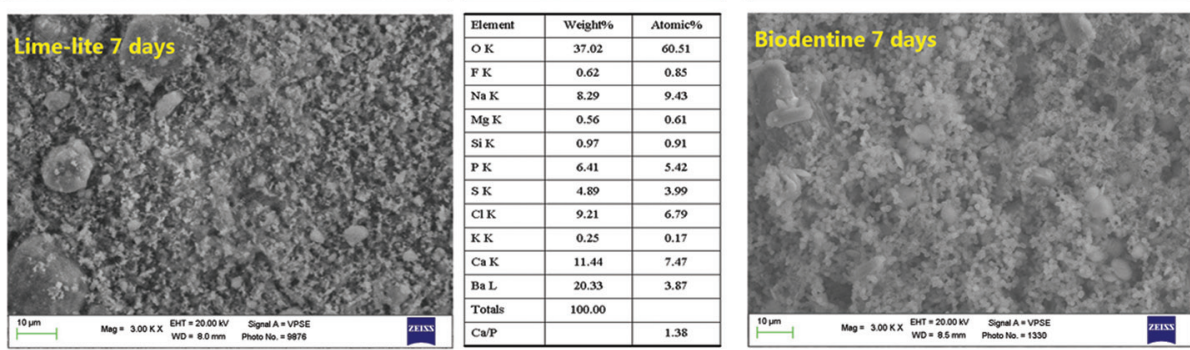

\begin{tabular}{|l|l|l|}
\hline Element & Weight\% & Atomic\% \\
\hline $\mathrm{C} \mathrm{K}$ & $\mathbf{8 . 7 5}$ & $\mathbf{1 4 . 4 1}$ \\
\hline $\mathrm{O} \mathrm{K}$ & 50.61 & 62.54 \\
\hline $\mathrm{Na} \mathrm{K}$ & 1.20 & $\mathbf{1 . 0 3}$ \\
\hline $\mathrm{Mg} \mathrm{K}$ & 4.32 & 3.51 \\
\hline $\mathrm{Si} \mathrm{K}$ & 1.07 & 0.75 \\
\hline $\mathrm{P} \mathrm{K}$ & 5.64 & 3.60 \\
\hline $\mathrm{Cl} \mathrm{K}$ & $\mathbf{2 . 0 4}$ & $\mathbf{1 . 1 4}$ \\
\hline $\mathrm{Ca} \mathrm{K}$ & 26.38 & $\mathbf{1 3 . 0 1}$ \\
\hline Totals & 100.00 & \\
\hline CalP & & 3.61 \\
\hline
\end{tabular}
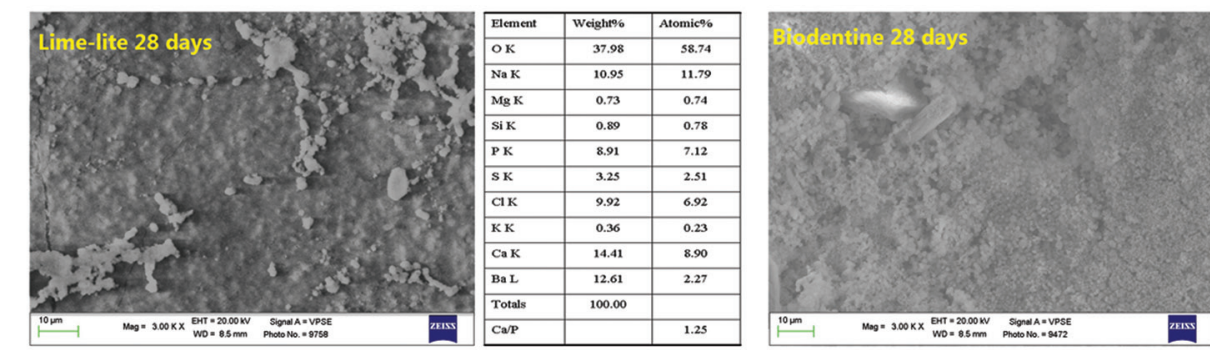

\begin{tabular}{|l|l|l|}
\hline Element & Weight\% & Atomic\% \\
\hline $\mathrm{C} \mathrm{K}$ & 5.46 & 9.32 \\
\hline $\mathrm{O} \mathrm{K}$ & 51.02 & 65.38 \\
\hline $\mathrm{Na} \mathrm{K}$ & 1.24 & 1.10 \\
\hline $\mathrm{Mg} \mathrm{K}$ & 3.12 & 2.63 \\
\hline $\mathrm{Si} \mathrm{K}$ & 0.99 & 0.72 \\
\hline $\mathrm{P} \mathrm{K}$ & $\mathbf{8 . 0 5}$ & 5.33 \\
\hline $\mathrm{Cl} \mathrm{K}$ & 1.57 & 0.91 \\
\hline $\mathrm{Ca} \mathrm{K}$ & 28.55 & 14.60 \\
\hline Totals & 100.00 & \\
\hline $\mathrm{C} a \mathrm{P}$ & & 2.74 \\
\hline
\end{tabular}

Fig. 1 - Morphochemical analysis by environmental scanning electron microscopy with energy-dispersive X-ray analysis (ESEM-EDX) of Dycal, Life, Lime-Lite and Biodentine. 


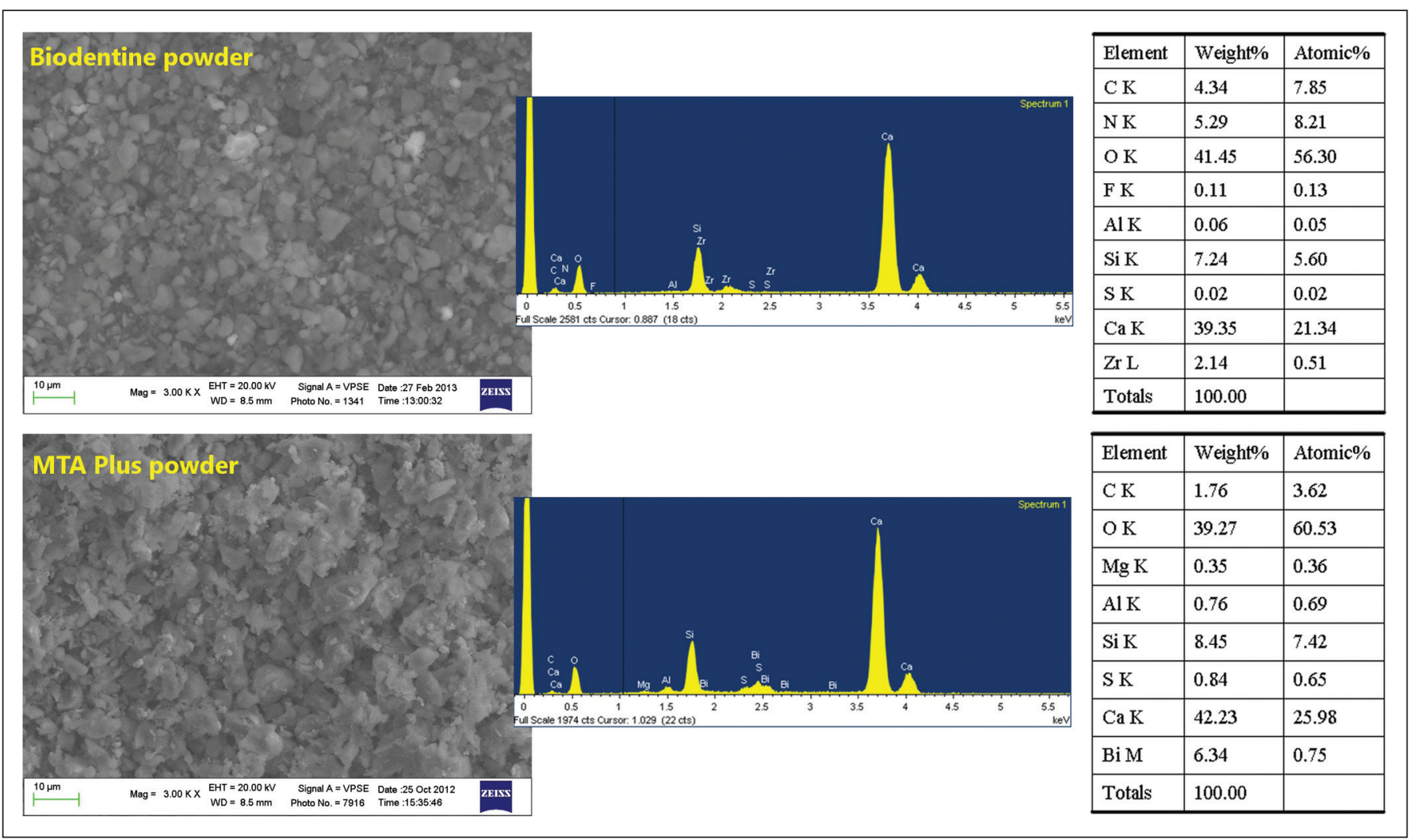

Fig. 2 - Environmental scanning electron microscopy with energy-dispersive X-ray analysis (ESEM-EDX) analysis of unhydrated powders of Biodentine and MTA Plus.

$\mathrm{P}$ appeared and increased in intensity with the soaking time. The $\mathrm{Ca} / \mathrm{P}$ atomic ratio at 28 days was 2.62.

\section{MTA Plus gel}

Freshly mixed MTA Plus gel (Fig. 3) displayed a granular surface showing mainly $\mathrm{Ca}$ and $\mathrm{Si}$ (from dicalcium and tricalcium silicates). $\mathrm{Al}(0.63 \% \mathrm{wt}), \mathrm{Bi}(11.27 \% \mathrm{wt})$ and $\mathrm{S}(0.63 \% \mathrm{wt})$, likely from calcium aluminate, bismuth oxide and calcium sulphate, respectively, were noted. Prominent C (5.9\% wt) and N $(4.58 \% \mathrm{wt}$, likely due to the presence of an organic polymer) components were also detected with $\mathrm{F}(1.2 \% \mathrm{wt}$, possibly from a nonstated fluoride component) and traces of $\mathrm{Mg}(0.24 \% \mathrm{wt})$. After 7 days, the reflexes of $\mathrm{Si}, \mathrm{N}, \mathrm{F}$ and $\mathrm{Bi}$ decreased in intensity, and the $\mathrm{P}$ element became detectable. $\mathrm{N}, \mathrm{F}$ and $\mathrm{Bi}$ disappeared with soaking in HBSS. C remained almost constant throughout the soaking time. At 28 days, the surface was coated by a thick layer of globular CaP precipitates, and the $\mathrm{Ca} / \mathrm{P}$ atomic ratio was 2.63. Additional ESEM-EDX analyses on unhydrated powder (Fig. 2) revealed the following elements (in percentage weight): C $(1.76 \%), \mathrm{Mg}(0.35 \%)$, Si (8.45\%), Al (0.76\%), S (0.84\%), $\mathrm{Ca}(42.23 \%)$ and $\mathrm{Bi}(6.34 \%)$, and the absence of both $\mathrm{F}$ and $\mathrm{N}$.

\section{ProRoot MTA}

Freshly mixed ProRoot MTA (Fig. 3) displayed a finely granular surface revealing $\mathrm{Ca}$ and $\mathrm{Si}$ (from calcium silicates), $\mathrm{Al}(0.74 \% \mathrm{wt})$ and $\mathrm{Bi}(9.6 \% \mathrm{wt}$, likely from calcium aluminate and calcium alumino-ferrite and bismuth oxide) and C (3.67\% wt). No $S$ was detected at any time. After 7 days in HBSS, the $\mathrm{P}$ element and traces of $\mathrm{Na}$ and $\mathrm{Cl}$ (from the HBSS) were noted. A high Mg peak was detected. The reflexes of the components $\mathrm{Si}$ and $\mathrm{Bi}$ decreased in intensity, while C $(8.55 \% \mathrm{wt})$ increased. No S was detected. Following 28 days in HBSS, the surface was coated by irregularly distributed globular $\mathrm{CaP}$ precipitates so Bi was still detectable. No S was found, and a high C (15\% wt) component was noted probably due to a carbonation phenomenon after prolonged soaking. The $\mathrm{Ca} / \mathrm{P}$ atomic ratio was 1.84 .

\section{Tech Biosealer capping}

Freshly mixed Tech Biosealer capping (Fig. 4) displayed a surface composed of agranular areas interspersed with granular zones. Ca and $\mathrm{Si}$ (from di calcium and tricalcium silicates), $\mathrm{Al}$ (0.9\% wt from calcium aluminate), $\mathrm{Cl}$ (12.4\% wt, from calcium chloride), S $(1.25 \% \mathrm{wt}$, from calcium 

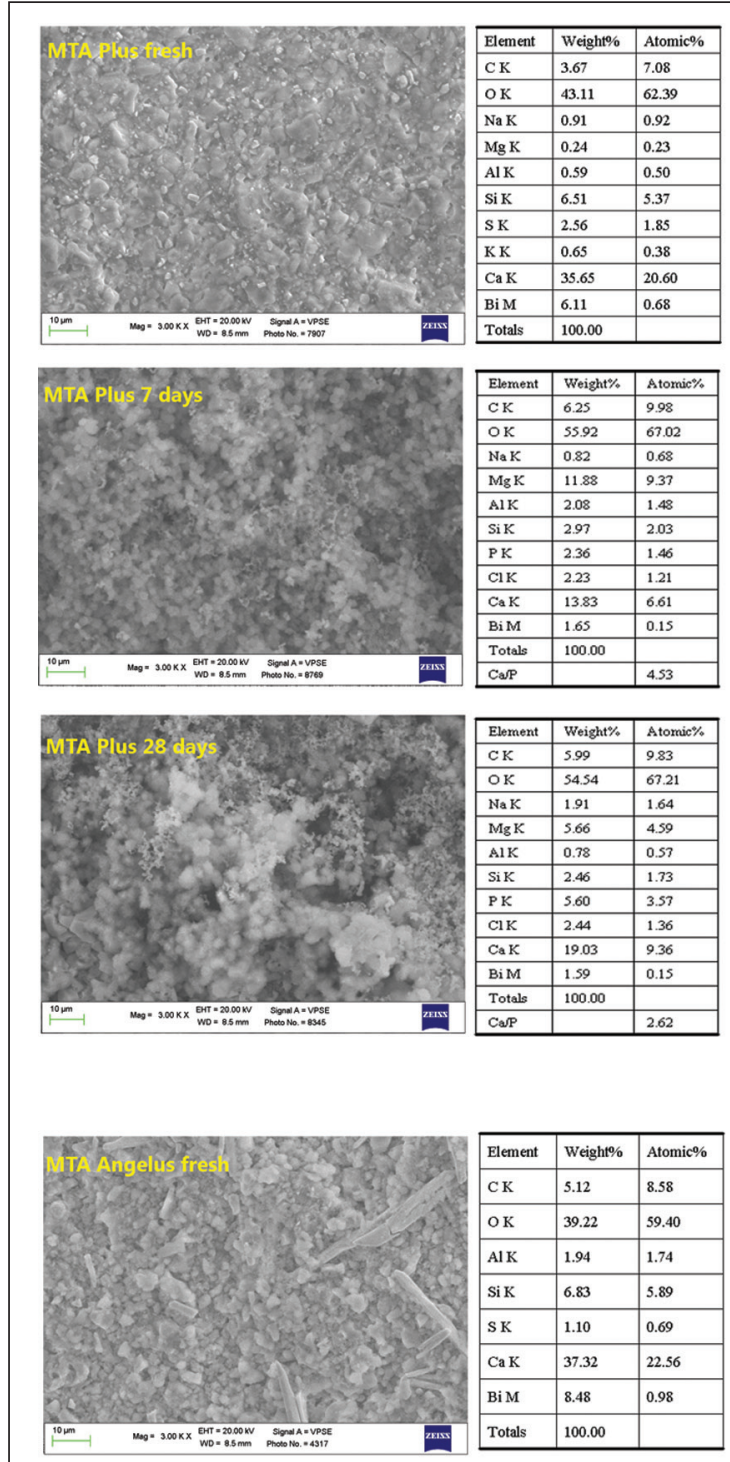

\begin{tabular}{|l|l|l|}
\hline Element & Weight\% & Atomic\% \\
\hline $\mathrm{C} \mathrm{K}$ & 5.12 & 8.58 \\
\hline $\mathrm{O} \mathrm{K}$ & 39.22 & 59.40 \\
\hline $\mathrm{Al} \mathrm{K}$ & 1.94 & 1.74 \\
\hline $\mathrm{Si} \mathrm{K}$ & 6.83 & 5.89 \\
\hline $\mathrm{S} \mathrm{K}$ & 1.10 & 0.69 \\
\hline $\mathrm{Ca} \mathrm{K}$ & 37.32 & 22.56 \\
\hline Bi M & 8.48 & 0.98 \\
\hline Totals & 100.00 & \\
\hline
\end{tabular}
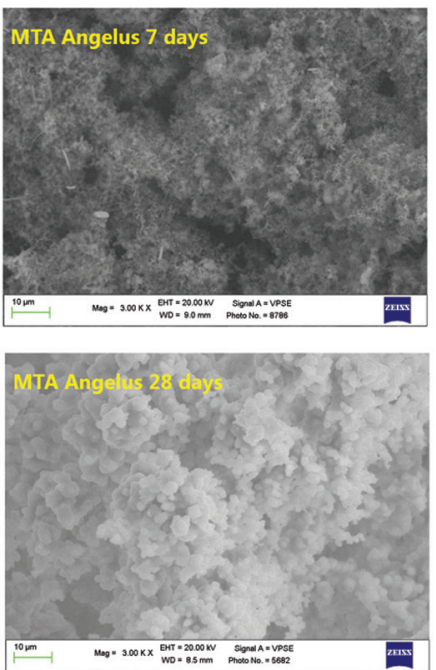
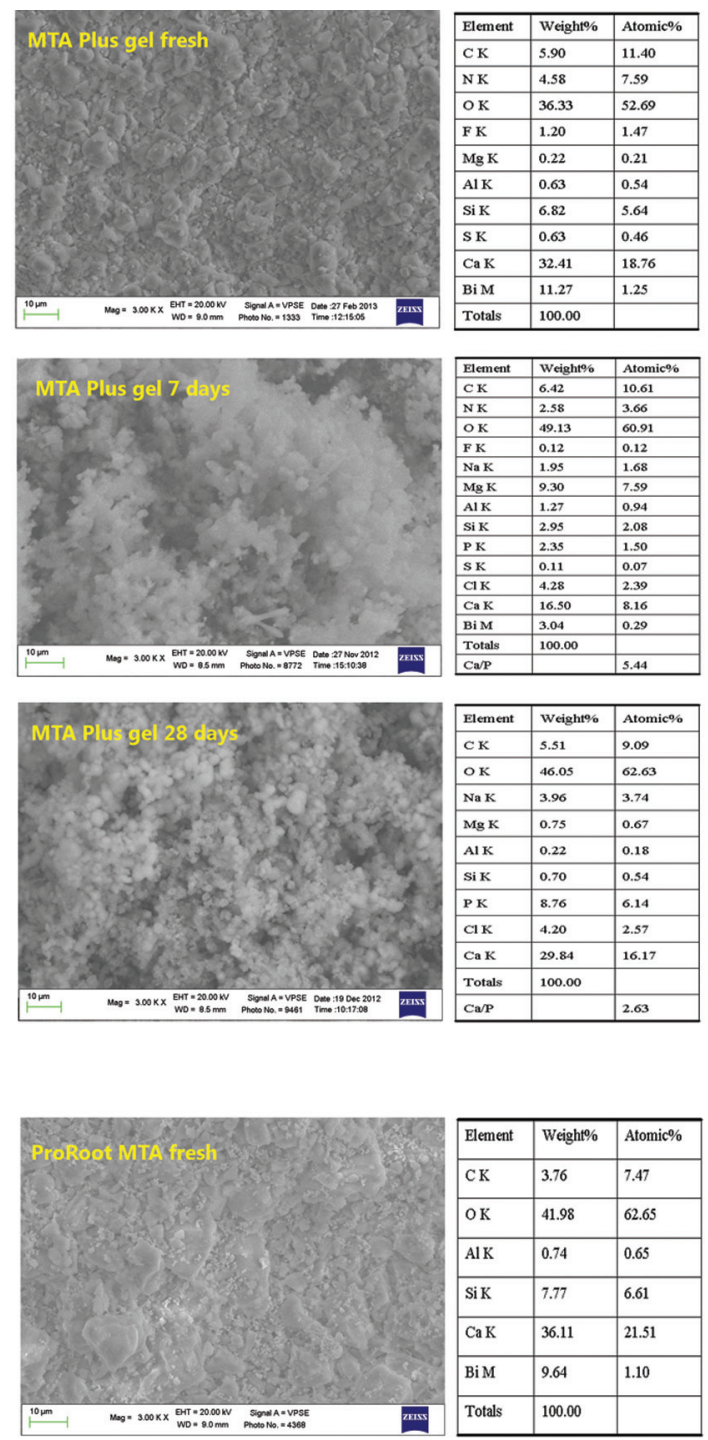

\begin{tabular}{|l|l|l|}
\hline Element & Weight\% & Atomic\% \\
\hline C K & 3.76 & 7.47 \\
\hline O K & 41.98 & 62.65 \\
\hline Al K & 0.74 & 0.65 \\
\hline Si K & 7.77 & 6.61 \\
\hline Ca K & 36.11 & 21.51 \\
\hline Bi M & 9.64 & 1.10 \\
\hline Totals & 100.00 & \\
\hline
\end{tabular}
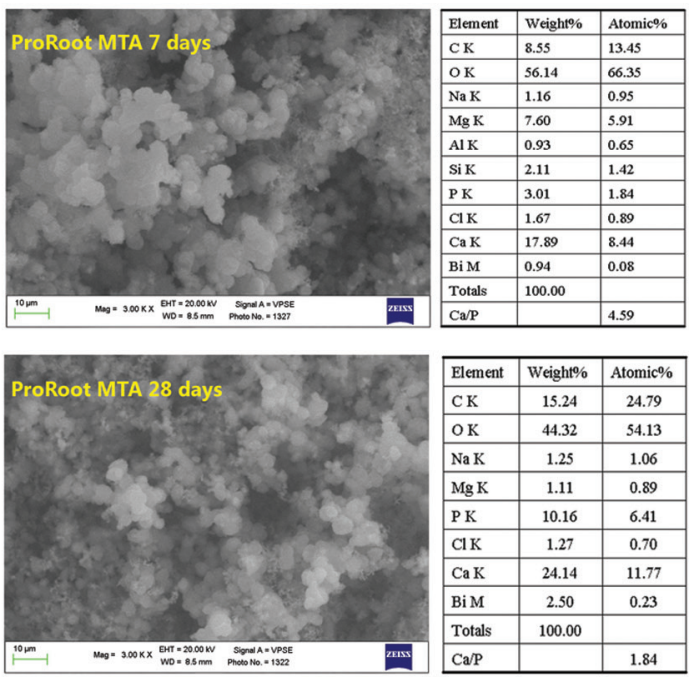

\begin{tabular}{|l|c|c|}
\hline Element & Weight\% & Atomic\% \\
\hline $\mathrm{C} \mathrm{K}$ & 15.24 & 24.79 \\
\hline $\mathrm{O} \mathrm{K}$ & 44.32 & 54.13 \\
\hline $\mathrm{Na} \mathrm{K}$ & 1.25 & 1.06 \\
\hline $\mathrm{Mg} \mathrm{K}$ & 1.11 & 0.89 \\
\hline $\mathrm{P} \mathrm{K}$ & 10.16 & 6.41 \\
\hline $\mathrm{Cl} \mathrm{K}$ & 1.27 & 0.70 \\
\hline $\mathrm{Ca} \mathrm{K}$ & 24.14 & 11.77 \\
\hline $\mathrm{Bi} \mathrm{M}$ & 2.50 & 0.23 \\
\hline Totals & 100.00 & \\
\hline Ca/P & & 1.84 \\
\hline
\end{tabular}

Fig. 3 - Environmental scanning electron microscopy with energy-dispersive X-ray analysis (ESEM-EDX) analysis of MTA Plus, MTA Angelus and ProRoot MTA. 


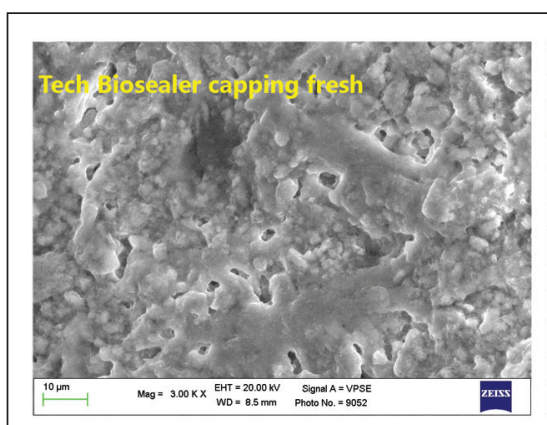

\begin{tabular}{|l|l|l|}
\hline Element & Weight\% & Atomic\% \\
\hline $\mathrm{C} \mathrm{K}$ & 12.44 & 22.30 \\
\hline $\mathrm{O} \mathrm{K}$ & 32.95 & 44.35 \\
\hline $\mathrm{Na} \mathrm{K}$ & 3.54 & 3.31 \\
\hline $\mathrm{Mg} \mathrm{K}$ & 0.42 & 0.38 \\
\hline $\mathrm{Al} \mathrm{K}$ & 0.92 & 0.73 \\
\hline $\mathrm{Si} \mathrm{K}$ & 3.96 & 3.04 \\
\hline $\mathrm{S} \mathrm{K}$ & 1.25 & 0.84 \\
\hline $\mathrm{Cl} \mathrm{K}$ & 15.93 & 9.68 \\
\hline $\mathrm{K} \mathrm{K}$ & 0.79 & 0.44 \\
\hline Ca K & 27.81 & 14.95 \\
\hline Totals & 100.00 & \\
\hline & & \\
\hline
\end{tabular}

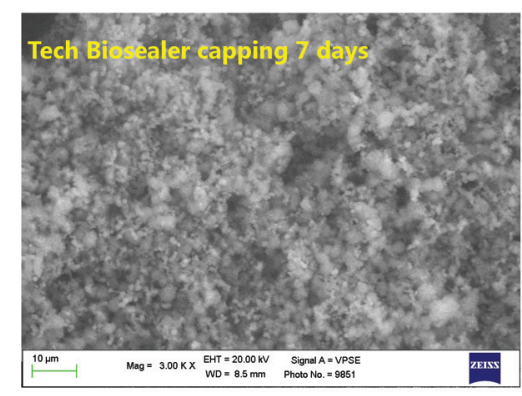

\begin{tabular}{|l|l|l|}
\hline Element & Weight\% & Atomic\% \\
\hline $\mathrm{C} \mathrm{K}$ & 5.01 & 8.09 \\
\hline $\mathrm{O} \mathrm{K}$ & 55.12 & 66.89 \\
\hline $\mathrm{Na} \mathrm{K}$ & 2.09 & 1.77 \\
\hline $\mathrm{Mg} \mathrm{K}$ & 11.05 & 8.82 \\
\hline $\mathrm{Al} \mathrm{K}$ & 1.60 & 1.15 \\
\hline $\mathrm{Si} \mathrm{K}$ & 1.27 & 0.88 \\
\hline $\mathrm{P} \mathrm{K}$ & 4.04 & 2.53 \\
\hline $\mathrm{Cl} \mathrm{K}$ & 4.25 & 2.33 \\
\hline $\mathrm{Ca} \mathrm{K}$ & 15.57 & 7.54 \\
\hline Totals & 100.00 & \\
\hline $\mathrm{Ca} / \mathrm{P}$ & & 2.98 \\
\hline
\end{tabular}

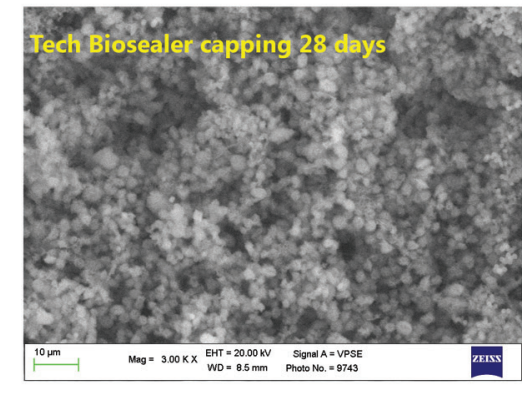

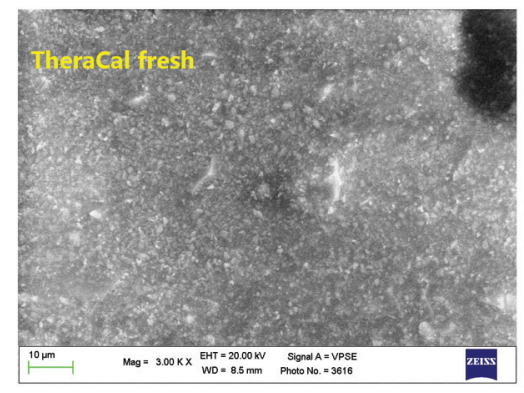

\begin{tabular}{|l|l|l|}
\hline Element & Weight $\%$ & Atomic $\%$ \\
\hline $\mathrm{C} \mathrm{K}$ & 28.37 & 40.62 \\
\hline $\mathrm{N} \mathrm{K}$ & 4.55 & 6.32 \\
\hline $\mathrm{O} \mathrm{K}$ & 39.39 & 42.35 \\
\hline $\mathrm{Al} \mathrm{K}$ & 2.20 & 1.40 \\
\hline $\mathrm{Si} \mathrm{K}$ & 9.86 & 6.04 \\
\hline $\mathrm{S} \mathrm{K}$ & 1.08 & 0.58 \\
\hline $\mathrm{Ca} \mathrm{K}$ & 7.95 & 3.41 \\
\hline $\mathrm{Ba} \mathrm{L}$ & 2.81 & 0.35 \\
\hline $\mathrm{W} \mathrm{M}$ & 3.77 & 0.35 \\
\hline Totals & 100.00 & \\
\hline
\end{tabular}
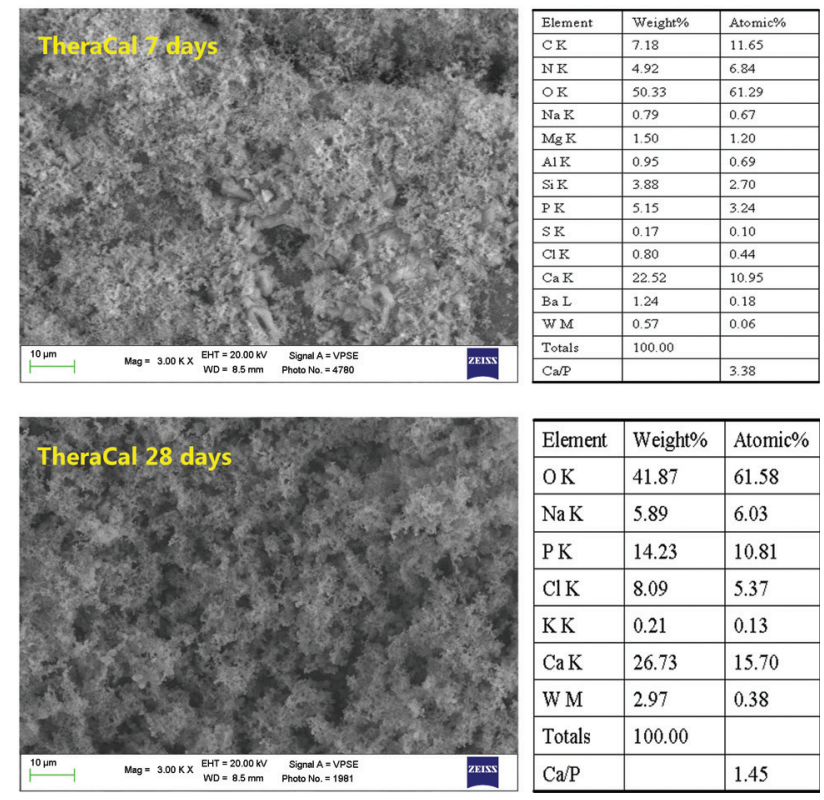

Fig. 4 - Morphochemical analysis of Tech Biosealer capping and TheraCal.

sulphate) and C (12.44\% wt likely due to the presence of carbonates). Amounts of $\mathrm{Na}, \mathrm{K}$ and $\mathrm{Mg}$ (from the Dulbecco's phosphate-buffered saline mixing liquid) were also noted. No Bi was detected. After soaking in HBSS, the P element was detected and the reflexes of the $\mathrm{Si}, \mathrm{Al}$ and $\mathrm{S}$ components decreased in intensity. A high $\mathrm{Mg}$ peak and $\mathrm{C}(5 \% \mathrm{wt})$ were detected at 7 days. At 28 days, the surface was uniformly coated by a layer of clear-cut CaP spherulites, and the $\mathrm{Ca} / \mathrm{P}$ atomic ratio was 3.69 .

\section{TheraCal}

Fresh TheraCal (Fig. 4) showed a homogeneous finely granular surface and displayed $\mathrm{Ca}, \mathrm{Si}, \mathrm{S}(1 \% \mathrm{wt})$ and $\mathrm{Al}$ (2.2\% wt) elements from Portland cement. Ba $(2.81 \% \mathrm{wt})$ and $\mathrm{W}(3.77 \% \mathrm{wt})$ elements (from nondisclosed components, possibly barium sulphate and calcium tungstate) were also detected. A prominent C (28.37\% wt) and C and $\mathrm{N}$ peaks $(4.55 \% \mathrm{wt})$ from the resin were detected. Traces of $\mathrm{Mg}, \mathrm{Na}$ and $\mathrm{Cl}$ (from the HBSS) were detected after soaking, and the P element was evident. The reflexes of the components as $\mathrm{Si}, \mathrm{W}, \mathrm{Ba}, \mathrm{Al}, \mathrm{S}, \mathrm{C}$ and $\mathrm{N}$ decreased progressively in intensity with soaking in HBSS. At 28 days many elements ( $\mathrm{Si}, \mathrm{Al}, \mathrm{S}, \mathrm{Ba}, \mathrm{N}$ and $\mathrm{C}$ ) became undetectable as screened by a coating of deposits. An uneven layer of CaP spherulites was present on the surface, and the $\mathrm{Ca} / \mathrm{P}$ atomic ratio was 1.45 and the $\mathrm{Ca} / \mathrm{P}$ molar ratio 2.43.

\section{DISCUSSION}

The ability to release calcium and hydroxide ions is a key factor for successful pulp capping therapy because of the action of calcium on pulp cell differentiation and hard tissue mineralization (28-33). Calcium ions are necessary for the differentiation and mineralization of pulp cells (28), and Ca ions specifically modulate osteopontin and bone morphogenetic protein-2 levels during pulp calcification (34). In addition, the eluted Ca ions increase the proliferation of human dental pulp cells in a dosedependent manner $(31,35)$, and Ca release enhances the activity of pyrophosphatase, which helps to maintain 
dentine mineralization and the formation of a dentine bridge (36). Moreover, hydroxide ions stimulate the release of alkaline phosphatase and BMP-2, which participate in the mineralization process $(37,38)$. Several studies have demonstrated that both calcium hydroxide- and calcium silicate-based materials share their properties to stimulate the reparative hard tissues $(16,17,19,39,40)$.

Ion release depends on the nature of the mineral particles and on the network structure of the cement responsible for water sorption and solubility as well the permeability of the material to water diffusion (i.e., porosity). With the exception of conventional calcium hydroxide formulations (Calxyl) that underwent rapid and complete solubilization, the present study showed that calcium silicate-containing materials released more free calcium ions than calcium hydroxide resin-containing materials.

Calxy ${ }^{\circledR}$ is a self-setting material containing pure calcium hydroxide with or without radiopacifying agent. This study showed that both radiopaque and nonradiopaque Calxyl formulations fully dissolved after 1 day of immersion providing more than $300 \mathrm{ppm}$ of $\mathrm{Ca}$ ions and increasing the $\mathrm{pH}$ of soaking water to almost 13. Such high solubility and fast dissolution are typical drawbacks of conventional calcium hydroxide materials, making them clinically inadequate in bleeding sites. Such solubility made it impossible to carry out the bioactivity test.

Dyca ${ }^{\circledR}$ is a self-setting radiopaque calcium hydroxide material containing sulphonamide (plasticizer) butylene glycol disalicylate (setting activator), which was introduced back in 1962 (41).

Life $^{\circledR}$ is a self-curing calcium hydroxide-based material containing zinc oxide and a resin phase (methyl salicylate and butyl benzene sulphonamide). The setting reaction in both Dycal and Life leads to the formation of Ca-salicylate chelate through an acid-base reaction (Ca ions replace acidic phenolic protons in the carbonyl groups of the salicylate) thereby generating free water (by the combination of $\mathrm{OH}^{-}$from $\mathrm{Ca}(\mathrm{OH})_{2}$ with $\mathrm{H}^{+}$from phenolic groups) absorbed into the structure of the setting materials. The presence of a resin phase is likely correlated with the low solubility of these materials, although the solubility values can be enhanced by the free water formation. Dycal and Life showed similar solubility $(4.91 \%$ and $3.98 \%)$ and apparent porosity $(9.04 \%$ and $7.49 \%)$ and water sorption $(5.06 \%$ and $4.41 \%)$ values, all statistically lower than those of the other materials.

In the present study, Dycal showed low solubility $(4.91 \%)$ as reported in a previous study (42) performed following American Dental Association specification \#8 (zinc phosphate cement solubility). Despite their low solubility and porosity, Dycal and Life showed a marked calcium release, as reported in other studies $(25,43,44)$. They also proved to have a hydrophilic nature allowing the free passage of water and making them hydrolytically susceptible to aqueous attack, in agreement with previous data (45). So, due to their hydrolytic instability, these materials leak calcium and hydroxide when in contact with water, as shown by their calcium release and the ability to slightly basify the $\mathrm{pH}$ of the aqueous environment. In terms of alkalization, Dycal strongly increased the $\mathrm{pH}$ of soaking water after 3 hours of immersion and kept the $\mathrm{pH}$ values above 9.16 throughout all tested end points. By contrast, Life demonstrated a lack of alkalization ability as the $\mathrm{pH}$ of the soaking media was between 7.33 and 7.62, in agreement with the results of previous studies $(43,44)$.

The increase in free $\mathrm{Ca}$ ions together with a basic $\mathrm{pH}$ are undoubtedly connected with the appreciable formation of CaP deposits by both Dycal and Life. Moreover, the salicylate and zinc oxide in the composition, acting as Ca-chelating agents, probably facilitate the deposition of calcium phosphate (23). Our EDX analyses disclosed $\mathrm{C}$ and S (3.5\%-5.5\% wt) elements typical of the sulphonamide component and the formation of a CaP layer thick and dense enough to strongly reduce EDX detection of the ingredients.

Lime-Lite $^{\circledR}$ is a fairly recent light-curing radiopaque material containing hydroxyapatite and fluoride salt in a urethane dimethacrylate resin (46). The technical data sheet reports its ability to release calcium, fluoride and hydroxyl ions and the presence of hydroxyapatite. Despite the manufacturer's claims, the present study found a negligible amount of $\mathrm{F}(0.21 \% \mathrm{wt})$ and a low $\mathrm{P}$ content $(1 \% \mathrm{wt})$ on fresh material. The detected $\mathrm{Ba}(9 \% \mathrm{wt})$ and S $(4.9 \% \mathrm{wt})$ can be attributed to the radiopacifier barium sulphate and the $\mathrm{C}$ and $\mathrm{Si}(1.3 \% \mathrm{wt})$ elements to the silica-containing rubberized urethane ${ }^{\mathrm{TM}}$ recently introduced by Pulpdent.

Lime-lite showed a high rate of water sorption (8.9\%), but the solubility was very low $(1.7 \%)$ and ion release scant, despite the manufacturer's claims. The high water sorption is likely to cause a hygroscopic expansion. A layer of $\mathrm{CaP}$ deposits was detected on the surface with soaking time, and the $\mathrm{Ca} / \mathrm{P}$ atomic ratio at 28 days was 1.25 , consistent with non-apatitic calcium phosphates (23). The material showed a fair ability to form CaP (not properly definable as bioactivity), likely due to the presence of a methacrylate resin (18).

Although white ProRoot MTA, white MTA Angelus and MTA Plus have a similar composition (Portland cement and bismuth oxide), in the present study their ionreleasing, solubility, water sorption and porosity differed widely, likely due to chemical and particle size differences in the sintered (clinkered) calcium silicate-calcium aluminate mineral powder.

ProRoot MTA showed a scant Ca release compared with the other calcium silicate cements and the lowest solubility among them. The low solubility can also be correlated with the low L/P ratio (L/P 0.31) compared with the other MTAs (namely, the water content by weight was ProRoot MTA $23.66 \%$, MTA Angelus 37.5\%, MTA Plus $26.83 \%$ and Tech Biosealer capping $28.57 \%$, with the 
exceptions of Biodentine containing $20.45 \mathrm{wt} \%$ of a nonwater-based liquid and MTA Plus gel containing $75 \mathrm{wt} \%$ of a water-based gel). ESEM-EDX analyses after soaking in HBSS showed the formation of well-defined rounded agglomerates (approx. $5 \mu \mathrm{m}$ in diameter); $\mathrm{S}$ was never detected, indicating the probable absence of a calcium sulphate component typical of Portland cement. Prominent carbonation phenomena (high C content after soaking) were found for ProRoot MTA.

MTA Angelus showed the strongest alkalizing effect and the highest water sorption (37\%), apparent porosity $(49.5 \%)$ and solubility $(29.55 \%)$ associated with Ca release and good bioactivity. A strongly uneven particle size of the freshly mixed powder, ranging from 2 to $30 \mu \mathrm{m}$, was noted. The appreciable amount of Ca release can be correlated with the high value of apparent porosity $(40 \%)$ that encourages ion exchange.

MTA Plus is an inexpensive material packaged in 8-g powder bottles proposed for treating dental pulp (pulp capping, cavity lining, pulpotomies) and root canals (rootend filling, perforation repair, root resorption, apexification and obturation in pulpectomy), and introduced in 2011. MTA Plus has a composition similar to the toothcolored ProRoot MTA but consisting of a finer mineral powder that can be mixed with 2 different liquids provided (water or a gel) to obtain materials with different setting times (47).

In our study, MTA Plus showed high Ca release correlated with the presence of calcium silicates and higher water sorption $(24.87 \%)$, porosity $(40 \%)$ and solubility $(18.55 \%)$ than ProRoot MTA. EDX analyses disclosed $\mathrm{Ca}, \mathrm{Si}, \mathrm{Cl}, \mathrm{Al}, \mathrm{S}$ and $\mathrm{Bi}$, consistent with the presence of calcium silicates, calcium sulphate, calcium aluminate, calcium chloride and bismuth oxide. MTA Plus showed good bioactivity and the formation of a thick CaP layer after soaking in simulated body fluid. Additional ESEMEDX analyses performed on unmixed powder showed the absence of $\mathrm{Na}$ and $\mathrm{K}$ reflexes, indicating that the mixing liquid could contain salts.

MTA Plus gel showed very high Ca release and $\mathrm{pH}$. Apparent porosity $(39.30 \%)$ and solubility $(14.68 \%)$ were reduced by mixing with gel. The material showed a very low solubility considering that $75 \mathrm{wt} \%$ of its initial weight was water-based gel. The bioactivity was pronounced, with the formation of large calcium phosphate-based spherulites. Unexpectedly, EDX revealed $F(1.2 \% \mathrm{wt})$ not disclosed by the manufacturer and likely introduced to modify the expansion and bioactivity of the cement $(21,48,49)$. The detection of $\mathrm{C}$ and $\mathrm{N}$ elements suggests the presence of an organic polymer that could be $\mathrm{N}$-vinylpyrrolidone $\left(\mathrm{C}_{6} \mathrm{H}_{9} \mathrm{NO}\right)_{n}$ given its characteristic smell and colorless nature. This monomer may have been introduced to modify and improve the rheological properties of the material by acting as a suspending agent, stabilizer, flow promoter and binder. The manufacturer states the gel's ability to impart washout resistance and to speed up the setting time. Microanalyses on unhydrated powder showed the absence of both $\mathrm{F}$ and $\mathrm{N}$ and a small amount of $\mathrm{C}$, suggesting the presence of organic ingredients and an F-containing salt, likely sodium fluoride, in the mixing fluid gel.

Summarizing, among all the tested MTA materials, MTA Plus gel showed the highest release of $\mathrm{Ca}$ ions at early end points ( 3 hours to 1 day) but not the highest solubility, water sorption or apparent porosity; those were found in MTA Angelus. ProRoot MTA demonstrated the lowest Ca release, solubility $(10.89 \%)$ and apparent porosity $(29.36 \%)$. The ion-releasing values obtained for ProRoot MTA are lower than others have previously reported $(18,25)$ despite the same methodology. However, the fact that the tested batches differed confirms that the composition and consequently the chemical-physical behavior of ProRoot MTA changes from one lot to the next. Conversely, the chemical-physical data of MTA Angelus and Dycal showed similar values to those reported in other studies $(18,25,42)$.

Biodentine and Tech Biosealer capping are calcium silicate cements introduced in 2010 with formulations quite different from the other MTAs tested. Biodentine is a tricalcium silicate-based material $(50,51)$ composed of a powder packaged in capsules $(0.7 \mathrm{~g})$ to be mixed with a liquid phase $(0.18 \mathrm{~mL})$ containing calcium chloride. Biodentine has the drawback of requiring an amalgam vibrator for its preparation and that prevents the clinician from adjusting the fluidity of the paste by regulating the amount of mixing liquid. In the present study Biodentine showed a high release of $\mathrm{Ca}$ ions and alkalizing activity. SEM analyses of fresh Biodentine showed a surface strongly different from that of the other calcium silicate materials, with particles appearing suspended in a matrix. EDX displayed $\mathrm{Ca}$ and $\mathrm{Si}$ due to the tricalcium silicate component, $\mathrm{Cl}$ from calcium chloride likely inserted to shorten the setting time (52) and C likely from calcium carbonate. Both C and N (3.95\% wt) are probably from (polyamino) carboxylates that could be present as a dispersant and water reducer (the mixing fluid was present only as $20.45 \%$ of the final paste). The detection of $\mathrm{Zr}(1.82 \% \mathrm{wt})$ was inconsistent with the stated composition, indicating the presence of undisclosed ingredients, likely zirconium oxide added as a radiopacifier and possibly tricalcium aluminates. S (correlated with the presence of sulphates) and $\mathrm{Al}$ elements were not detected. Additional microanalyses performed on unmixed calcium silicate powder also disclosed $\mathrm{C}, \mathrm{N}$ and $\mathrm{Zr}$, indicating that the supposed organic and radiopacifying components are ingredients of Biodentine powder.

The high Ca release can be correlated with the presence of a calcium silicate component and calcium chloride and low solubility $(11.83 \%)$ likely linked with the presence of a superplasticizer as a polycarboxylate commonly used to reduce the amount of water required (L/P 0.257) to disperse the particles and to enhance the fluidity, making the cement 
self-consolidating. In addition, the fast hydration reaction of tricalcium silicate can be correlated with the low solubility and high calcium release at early end points (a few hours). The large amount of calcium released favors the formation of $\mathrm{CaP}$ deposits. However the high $\mathrm{Ca} / \mathrm{P}$ atomic ratio (approx. 2.8) obtained at 28 days, together with the detection of a Si component, may be responsible for the thin or uneven $\mathrm{CaP}$ coating and the presence of calcium carbonate. Due to its favorable biological properties (biocompatibility, osteoconductivity, bioresorption and biomineralization) (53-55), calcium carbonate could have beneficial effects on mineralizing cell activation. Calcium carbonate is one of the most abundant and important biominerals in nature (it is deposited by osteoblasts together with calcium phosphates during the mineralization process), and both natural and synthetic forms are now used as biomaterials for tissue engineering.

In the present study, Biodentine showed the lowest solubility $(11.83 \%)$ of the calcium silicate -based cements, a slightly higher value than that stated by the manufacturer in the brochure $(6.8 \%)$. This low solubility can be correlated with the restricted amount of dispersing water-reducer superplasticizing mixing fluid likely based on polycarboxylic ether, as suggested by EDX data and by the patent, an idea taken from building materials (concrete) that does not represent a novelty or a new finding.

Tech Biosealer consists of 4 different formulations for specific clinical uses. In the present study the formulation specific for pulp capping procedure was analyzed. Tech Biosealer capping is a di-calcium and tricalcium silicate powder containing calcium chloride, calcium sulphate and montmorillonite as stabilizing and plasticizing agent $(21,24,48)$, packaged in unsealed 2-piece capsules. The high values of Ca release, solubility (27.87\%) and apparent porosity $(45.8 \%)$ found in the present study may be due to the presence of $\mathrm{CaCl}_{2}$ in the formulation, likely introduced to accelerate the setting time (52) and improve the release of $\mathrm{Ca}$ and its activating signal on pulp cells (28-34). No bismuth oxide was found, and the manufacturer's decision to produce a bismuth-free composition could be linked to the reduced biocompatibility induced by the bismuth element (56). Our EDX analyses showed a thick coating composed of well-defined globular CaP after 28 days in simulated body fluid; the high $\mathrm{Ca} / \mathrm{P}$ atomic ratio can be attributed to the presence of Ca-rich calcium phosphates and carbonated phases. Ca-rich ACP has been shown to turn into bone-like apatite through different kinetics mechanisms $(22,23,57)$.

TheraCal is a light-curable resin-based MTA-like material containing calcium silicate particles $(25,58)$ marketed as a ready-to-use paste. Our EDX analyses showed an organic matrix containing calcium silicates, aluminates and sulphates (likely barium sulphate). TheraCal showed low solubility $(2.75 \%)$ compared with the other materials, likely related to the presence of a light-curable resin, and the ability to release a moderate but rather constant amount of Ca ions, in agreement with Gandolfi et al (25). The material's considerable bioactivity is connected with the presence of silanol groups $(9,18)$ and resin groups $(18,23)$ able to promote the nucleation of calcium phosphate deposits.

In the present study, the calcium silicate-containing materials showed high biointeractivity (ion release) and bioactivity with high open pore volume and apparent porosity. The high open pore volume forms an internal network of water-filled pores providing a large surface area involved in the leaching process. The $\mathrm{Ca} / \mathrm{P}$ atomic ratio of the coating (range approx. 1.8-3.0) approached that of bone-like carbonate apatite more than that of the other calcium hydroxide-based materials.

All of the calcium silicate MTA-like formulations leached large amounts of $\mathrm{Ca}$ and $\mathrm{OH}$ ions, more than conventional calcium hydroxide resin-containing materials. The hydration reaction of the calcium silicate particles triggers the dissolution of their surface with the formation of a calcium silicate hydrate gel and $\mathrm{Ca}(\mathrm{OH})_{2}$, together with the release of $\mathrm{Ca}$ and $\mathrm{OH}$ ions. The porosity and water uptake tests in the present study were performed using Archimedes' principle as proposed by ASTM C373-88 and following ISO 3107.

The solubility test in the present study was performed following ISO 4049 calculating the decline in mass (weight loss) after storage in deionized water (18, 25, $59)$, and the results were expressed as a percentage of the specimen's original weight. The test measures the elution of water-soluble material and disintegrated portions. The explanation of the remarkable solubility of calcium silicate-based materials mainly lies in the formation, during the hydration and setting reactions, of soluble calcium salts and calcium hydroxide which are rapidly washed out by water. However, it is important to emphasize that most of the calcium silicate-based materials tested were prepared by mixing the mineral powder with a liquid (water or water-based liquid) using very different liquidto-powder weight proportions for each material. So, a prominent but unequal percentage of the initial material mass was constituted by mixing liquid, namely water (MTA Plus 26.83 wt\%, MTA Angelus 37.5 wt \%, ProRoot MTA $23.66 \mathrm{wt} \%$ and Tech Biosealer capping $28.57 \mathrm{wt} \%$ ) or water-based gel (MTA Plus gel $75 \mathrm{wt} \%$ ) or superplasticizer (Biodentine $20.45 \mathrm{wt} \%$ ) susceptible to evaporation in the drying procedure needed for the solubility test to obtain the final dry mass. This means that the reduction of the original weight obtained in the dry mass will not be entirely due to the solubility of the material, because much of the weight loss is caused by evaporation of the mixing free water during the final drying of the samples. All this must be taken into consideration in interpreting the solubility data for the water-containing calcium silicate-based cements. 
The hydration of calcium silicate cements proceeds by converting liquid (free) water into structural and constrained water. This process occurs mainly in the first few days and is considered almost complete after approx. 150 days. In particular, the hydration reaction of tricalcium silicate is almost complete (80\%) after 10 hours (in relation to the lower compactness of the tricalcium silicate crystal structure that favors the influx of water molecules) whereas that of dicalcium silicate is still partial (50\%) after 24 hours.

The solubility tests in the present study were performed after a period equal to $70 \%$ of the setting time of each material - i.e., 55 minutes for MTA Plus and Tech Biosealer capping, 80 minutes for MTA Angelus, 250 minutes for ProRoot MTA and 9 minutes for Biodentine. At these times, the hydration reaction is at the early stage and only a small part of the liquid free water can be converted into structural and constrained water, while most of the water can still be removed by the test drying procedure $\left(37^{\circ} \mathrm{C}\right)$ providing a high weight loss that does not truly correspond to the real solubility of the material. The results obtained from the solubility test of water-containing calcium silicate cements are overestimated referring to the clinical condition due to the contribution to the weight loss of the mixing free water of the prepared paste. Moreover, the leaching of water-soluble components and the correlated weight loss in clinical/biological conditions is different from that in deionized water: these bioactive materials benefit greatly from the presence of body fluids, and the formation of calcium phosphate deposits can improve their mass and fill porosities $(18,60)$.

Moreover, the presence of a biologically active partially porous material on the exposed pulp could trigger the activation of the pulp stem cells and improve the cell colonization of the material and the formation of reparative dentin.

\section{CONCLUSIONS}

The tested calcium silicate formulations are biointeractive bioactive functional biomaterials able to release biologically relevant ions and to induce the formation of calcium phosphate deposits. Their large open pore volume and water sorption provided a broad wet biointeractive surface correlated with their pronounced ion release.

The high rate of calcium release and the fast formation of apatite represent epigenetic signals for pulp cells and may explain the role and function of calcium silicate biomaterials as scaffolds to induce the formation of new reparative tissue (dentin bridge) and clinical healing.

Financial support: The research has been supported by the academic funds of the Master in Clinical Endontics of the University of Bologna (Dean Prof. Carlo Prati).

Conflict of interest: The authors declare they have no conflicts of interest related to this study.

Address for correspondence:

M. G. Gandolfi, DBiol, DSc, MSc, PhD

Laboratory of Biomaterials and Oral Pathology

(Unit of Odontostomatological Sciences)

Department of Biomedical and NeuroMotor Sciences

University of Bologna

Via San Vitale 59

IT-40125 Bologna, Italy

mgiovanna.gandolfi@unibo.it

\section{REFERENCES}

1. Hermann BW. Dentinobliteration der wuèrzelkanaèlen nach behandlung mit calzium [article in German]. Zahnarztl Rundsch. 1930; 21: 888-899.

2. Gandolfi MG, Baldi JV, Prati C. Biomaterials for pulp-capping: calcium-ions pulpflux through dentin in indirect pulpcapping [abstract]. J Dent Res. 2012; 1359: 91A. https:// iadr.confex.com/iadr/2012rio/webprogram/Paper165368. html.

3. Gandolfi MG. A new method for evaluating the pulpward diffusion of $\mathrm{Ca}$ and $\mathrm{OH}$ ions through coronal dentin into the pulp. Iran Endod J. 2012; 7(4): 189-197.

4. Goldberg M, Smith AJ. Cells and extracellular matrices of dentin and pulp: a biological basis for repair and tissue engineering. Crit Rev Oral Biol Med. 2004; 15(1): 13-27.
5. Adams GB, Chabner KT, Alley IR, et al. Stem cell engraftment at the endosteal niche is specified by the calciumsensing receptor. Nature. 2006; 439(7076): 599-603.

6. Siqueira JF Jr, Lopes HP. Mechanisms of antimicrobial activity of calcium hydroxide: a critical review. Int Endod J. 1999; 32(5): 361-369.

7. Athanassiadis B, Abbott PV, George N, Walsh LJ. An in vitro study of the antimicrobial activity of some endodontic medicaments and their bases using an agar well diffusion assay. Aust Dent J. 2009; 54(2): 141-146.

8. Okabe T, Sakamoto M, Takeuchi H, Matsushima K. Effects of $\mathrm{pH}$ on mineralization ability of human dental pulp cells. J Endod. 2006; 32(3): 198-201.

9. Gandolfi MG, Van Landuyt K, Taddei P, Modena E, Van Meerbeek B, Prati C. ESEM-EDX and Raman techniques to study MTA calcium-silicate cements in wet conditions and in real-time. J Endod. 2010; 36: 851-857. 
10. Gandolfi MG, Taddei P, Tinti A, Prati C. Apatite-forming ability (bioactivity) of ProRoot MTA. Int Endod J. 2010; 43(10): 917-929.

11. Parirokh $M$, Torabinejad M. Mineral trioxide aggregate: a comprehensive literature review: Part I: chemical, physical, and antibacterial properties. J Endod. 2010; 36(1): 16-27.

12. Camilleri J, Gandolfi MG. Evaluation of the radiopacity of calcium silicate cements containing different radiopacifiers. Int Endod J. 2010; 43(1): 21-30.

13. Torabinejad $M$, White DJ, inventors. Loma Linda University, Loma Linda, CA, applicant. Tooth filling material and method of use. Patent US 1998/5769638 and WO 94/24955. 1993.

14. Primus $C$, inventor. Dentsply International Inc., applicant. Dental material. Patent WO 02/056838, US 2004/0226478 (provisional application filed in 2001). 2004.

15. Torabinejad $M$, Parirokh $M$. Mineral trioxide aggregate: a comprehensive literature review: Part II: leakage and biocompatibility investigations. J Endod. 2010; 36(2): 190-202.

16. Gandolfi MG, Shah SN, Feng R, Prati C, Akintoye SO. Biomimetic calcium-silicate cements support differentiation of human orofacial mesenchymal stem cells. J Endod. 2011; 37(8): 1102-1108.

17. Gandolfi MG, Ciapetti G, Perut F, et al. Biomimetic calcium-silicate cements aged in simulated body solutions: osteoblast response and analyses of apatite coating. J Appl Biomater Biomech. 2009; 7(3): 160-170.

18. Gandolfi MG, Taddei P, Siboni F, Modena E, Ciapetti G, Prati C. Development of the foremost light-curable calciumsilicate MTA cement as root-end in oral surgery: chemicalphysical properties, bioactivity and biological behavior. Dent Mater. 2011; 27(7): e134-e157.

19. Okiji T, Yoshiba K. Reparative dentinogenesis induced by mineral trioxide aggregate: a review from the biological and physicochemical points of view. Int J Dent 2009; 2009: 1-12.

20. Pelliccioni GA, Vellani CP, Gatto MR, Gandolfi MG, Marchetti C, Prati C. Proroot mineral trioxide aggregate cement used as a retrograde filling without addition of water: an in vitro evaluation of its microleakage. J Endod. 2007; 33(9): 1082-1085.

21. Gandolfi MG, lacono F, Agee K, et al. Setting time and expansion in different soaking media of experimental accelerated calcium-silicate cements and ProRoot MTA. Oral Surg Oral Med Oral Pathol Oral Radiol Endod. 2009; 108(6): e39-e45.

22. Gandolfi MG, Taddei P, Tinti A, De Stefano Dorigo E, Rossi $\mathrm{PL}$, Prati C. Kinetics of apatite formation on a calciumsilicate cement for root-end filling during ageing in physiological-like phosphate solutions. Clin Oral Investig. 2010; 14(6): 659-668.

23. Gandolfi MG, Taddei P, Modena E, Siboni F, Prati C. Biointeractivity-related versus chemi/physisorption-related apatite precursor-forming ability of current root end filling materials. J Biomed Mater Res B Appl Biomater. 2013; 101(7): 1107-1123.

24. Gandolfi MG, Pagani S, Perut F, et al. Innovative silicatebased cements for endodontics: a study of osteoblast-like cell response. J Biomed Mater Res A. 2008; 87(2): 477-486.

25. Gandolfi MG, Siboni F, Prati C. Chemical-physical properties of TheraCal, a novel light-curable MTA-like material for pulp capping. Int Endod J. 2012; 45(6): 571-579.

26. Taddei P, Modena E, Tinti A, Siboni F, Prati C, Gandolfi MG. Vibrational investigation on the in vitro bioactivity of commercial and experimental calcium-silicate cements for rootend endodontic therapy. J Mol Struct 2011; 993: 367-375.

27. Jalota S, Bhaduri SB, Tas AC. Effect of carbonate content and buffer type on calcium phosphate formation in SBF solutions. J Mater Sci Mater Med. 2006; 17(8): 697-707.

28. Schröder U. Effects of calcium hydroxide-containing pulpcapping agents on pulp cell migration, proliferation, and differentiation. J Dent Res. 1985;64 (Spec No): 541-548.

29. Scarano A, Manzon L, Di Giorgio R, Orsini G, Tripodi D, Piattelli A. Direct capping with four different materials in humans: histological analysis of odontoblast activity. J Endod. 2003; 29(11): 729-734.

30. Moghaddame-Jafari S, Mantellini MG, Botero TM, McDonald NJ, Nör JE. Effect of ProRoot MTA on pulp cell apoptosis and proliferation in vitro. J Endod. 2005; 31(5): 387-391.

31. Takita T, Hayashi M, Takeichi O, et al. Effect of mineral trioxide aggregate on proliferation of cultured human dental pulp cells. Int Endod J. 2006; 39(5): 415-422.

32. Lopez-Cazaux S, Bluteau G, Magne D, Lieubeau B, Guicheux J, Alliot-Licht B. Culture medium modulates the behaviour of human dental pulp-derived cells: technical note. Eur Cell Mater. 2006; 11: 35-42, discussion 42.

33. Mizuno M, Banzai Y. Calcium ion release from calcium hydroxide stimulated fibronectin gene expression in dental pulp cells and the differentiation of dental pulp cells to mineralized tissue forming cells by fibronectin. Int Endod J. 2008; 41(11): 933-938.

34. Rashid F, Shiba H, Mizuno N, et al. The effect of extracellular calcium ion on gene expression of bone-related proteins in human pulp cells. J Endod. 2003; 29(2): 104-107.

35. Clapham DE. Calcium signaling. Cell. 1995; 80(2): 259-268.

36. Estrela C, Holland R. Calcium hydroxide: study based on scientific evidences. J Appl Oral Sci. 2003; 11(4): 269-282.

37. Estrela C, Sydney GB, Bammann LL, Felippe Júnior O. Mechanism of action of calcium and hydroxyl ions of calcium hydroxide on tissue and bacteria. Braz Dent J. 1995; 6(2): 85-90.

38. Okabe T, Sakamoto M, Takeuchi H, Matsushima K. Effects of $\mathrm{pH}$ on mineralization ability of human dental pulp cells. J Endod. 2006; 32(3): 198-201.

39. Ford TR, Torabinejad M, Abedi HR, Bakland LK, Kariyawasam SP. Using mineral trioxide aggregate as a pulp-capping material. J Am Dent Assoc. 1996; 127(10): 1491-1494.

40. Mente J, Geletneky B, Ohle M, et al. Mineral trioxide aggregate or calcium hydroxide direct pulp capping: an analysis 
of the clinical treatment outcome. J Endod. 2010; 36(5): 806-813.

41. Dougherty EW, inventor. LD Caulk Company, applicant. Dental cement material. Patent US 1962/3047408. 1962.

42. Francisconi LF, de Freitas AP, Scaffa PM, Mondelli RF, Francisconi PA. Water sorption and solubility of different calcium hydroxide cements. J Appl Oral Sci. 2009; 17(5): 427-431.

43. Saitoh M, Masutani S, Kojima T, Saigoh M, Hirose $H$, Nishiyama M. Thermal properties of dental materials: cavity liner and pulp capping agent. Dent Mater J. 2004; 23(3): 399-405.

44. Duarte MA, Martins CS, de Oliveira Cardoso Demarchi AC, de Godoy LF, Kuga MC, Yamashita JC. Calcium and hydroxide release from different pulp-capping materials. Oral Surg Oral Med Oral Pathol Oral Radiol Endod. 2007; 104(1): e66-e69.

45. Prosser HJ, Groffman DM, Wilson AD. The effect of composition on the erosion properties of calcium hydroxide cements. J Dent Res. 1982; 61(12): 1431-1435.

46. Stannard JG, Berk KJ, inventors. Polymerizable composite material. Patent US 2004/0132937, WO 2004/063274. 2004.

47. Primus C, inventor. Dental material. Patent US 7,892,342 B2. 2011.

48. Gandolfi MG, Prati C. MTA and F-doped MTA cements used as sealers with warm gutta-percha: longterm study of sealing ability. Int Endod J. 2010; 43(10): 889-901.

49. Gandolfi MG, Taddei P, Siboni F, Modena E, Ginebra MP, Prati C. Fluoride-containing nanoporous calcium-silicate MTA cements for endodontics and oral surgery: early fluorapatite formation in a phosphate-containing solution. Int Endod J. 2011; 44(10): 938-949.

50. Bergaya B, Bottero JY, Bottero MJ, et al, inventors. Septodont, applicant. WO 2004/017929, US 2010/7819663. 2010 .
51. Gilles R, Olivier M, inventors. Septodont, applicant. Dental composition. Patent WO 2011/124841, US 2013/ 0025498. 2011.

52. Abdullah D, Ford TR, Papaioannou S, Nicholson J, McDonald F. An evaluation of accelerated Portland cement as a restorative material. Biomaterials. 2002; 23(19): 4001-4010.

53. Combes C, Miao B, Bareille R, Rey C. Preparation, physical-chemical characterisation and cytocompatibility of calcium carbonate cements. Biomaterials. 2006; 27(9): 1945-1954.

54. Gallego D, Higuita N, Garcia F, Ferrell N, Hansford DJ. Bioactive coatings on Portland cement substrates: surface precipitation of apatite-like crystals. Mater Sci Eng C. 2008; 28(3): 347-352.

55. Dey A, de With G, Sommerdijk NA. In situ techniques in biomimetic mineralization studies of calcium carbonate. Chem Soc Rev. 2010; 39(2): 397-409.

56. Gandolfi MG, Ciapetti G, Taddei P, et al. Apatite formation on bioactive calcium-silicate cements for dentistry affects surface topography and human marrow stromal cells proliferation. Dent Mater. 2010; 26(10): 974-992.

57. Kim HM, Himeno T, Kokubo T, Nakamura T. Process and kinetics of bonelike apatite formation on sintered hydroxyapatite in a simulated body fluid. Biomaterials. 2005; 26(21): 4366-4373.

58. Suh B, Cannon M, Yin R, Martin D; Applicant Bisco Inc., Schaumburg, IL. Polymerizable dental pulp healing, capping, and lining material and method for use. Patent WO 2008/103712, US 2008/0318190. 2008.

59. Danesh G, Dammaschke T, Gerth HUV, Zandbiglari T, Schäfer E. A comparative study of selected properties of ProRoot mineral trioxide aggregate and two Portland cements. Int Endod J. 2006; 39(3): 213-219.

60. Gandolfi MG, Parrilli AP, Fini M, Prati C, Dummer PMH. 3D micro-CT analysis of the interface voids associated with Thermafil root fillings used with AH Plus or a flowable MTA sealer. Int Endod J. 2013; 46(3): 253-263. 